\title{
The prosodic representation of composite structures in Brazilian Portuguese ${ }^{1}$
}

\author{
NATÁLIA BRAMBATTI GUZZO
}

McGill University

(Received 30 November 2015; revised 26 January 2018)

In previous research, word-word compounds and stressed affix + word structures have been assigned to the same prosodic domain in Brazilian Portuguese (BP), on account of certain similarities in phonological behaviour (Silva 2010, Toneli 2014): both types of composite structures undergo vowel raising at the right edge of each element in the construction, and vowel sandhi processes between their elements. In this paper, I show that word-word compounds and stressed affix + word structures exhibit significant differences in stress patterns in BP, which supports their prosodization in two separate domains. While stressed affix + word structures are assigned secondary stress following the phonological word (PWd) stress algorithm, each element in word-word compounds behaves as an independent PWd with regard to the stress pattern that it exhibits. I thus propose that while stressed affix + word structures are recursively prosodized in the PWd domain, word-word compounds are prosodized in the composite group, the domain proposed by Vogel $(2008,2009)$ that immediately dominates the PWd and accounts for the prosodization of structures with compositional characteristics. The analysis reconciles two views on prosodic structure that are traditionally assumed to be mutually exclusive: the view that prosodic domains can be recursive (e.g. Inkelas 1990, Selkirk 1996) and the view that the prosodic hierarchy includes an additional domain specific to composite structures above the PWd (e.g. Vogel 2009, Vigário 2010).

\section{INTRODUCTION}

The representation of composite structures (such as word-word compounds and stressed affix + word structures) is an issue that has received considerable attention within the framework of Prosodic Phonology (since Selkirk 1984 and Nespor \& Vogel 1986). One of the fundamental premises of Prosodic Phonology is that the application of phonological processes is circumscribed to prosodic domains, which are formed via indirect mapping from the morphosyntactic component of the grammar. In other words, Prosodic Phonology assumes that phonological

[1] I would like to thank Heather Goad for carefully reading and commenting on earlier versions of this paper. I would also like to thank three anonymous reviewers for their helpful comments, the native speakers who were consulted, as well as Elisa Battisti, Guilherme Duarte Garcia, and Irene Vogel for valuable discussion. This research was supported in part by Brazil's Conselho Nacional de Desenvolvimento Científico e Tecnológico (CNPq) and the Social Sciences and Humanities Research Council of Canada. 
processes apply not in reference to morphosyntactic structures, but to the interpretation of such structures within the phonological component of the grammar. Each prosodic constituent, then, is the domain of application for particular phonological processes.

In Prosodic Phonology, it is standardly assumed that if two structures are mapped onto the prosodic hierarchy in the same way, they will undergo identical phonological processes (if their structural descriptions are met). Since multiple morphosyntactic structures may be assigned to a single prosodic domain, researchers often resort to the examination of phonological processes exhibited by a set of linguistic structures in order to access the form through which their syntax-phonology mapping occurs. Although morphosyntactic structures and prosodic domains do not match exactly, these two types of structures have a certain degree of correspondence. For example, lexical items are in general assumed to correspond to phonological words (PWds), whereas syntactic phrases are expected to be equivalent to phonological phrases (PPhs) (since Selkirk 1984 and Nespor \& Vogel 1986; see also Selkirk 2011).

Compounds (and composite structures in general) are often the object of prosodic analysis because their place in the hierarchy of prosodic domains is unclear. It is generally assumed that the combination of stems or independent lexical words corresponding to a single lexical item and a single conceptual unit (Partee 1994, Bauer 1998, Lieber \& Stekauer 2009) will be mapped onto the prosodic hierarchy as compounds. However, the prosodic representation of such structures depends on specific assumptions regarding the configuration of the prosodic hierarchy.

In earlier approaches to Prosodic Phonology, in which Non-Recursivity (prohibition of level repetition) and Exhaustivity (prohibition of level skipping) were inviolable principles in the organization of prosodic domains (e.g. Nespor \& Vogel 1986), there was no specific form of prosodization for composite structures. On the basis of the phonological behaviour of such structures, it was proposed that they could be prosodized as single PWds (e.g. Greek compounds in Nespor \& Vogel (1986)), PPhs (e.g. a subset of Greek compounds in Nespor \& Ralli (1996)), or clitic groups, the domain between the PWd and the PPh proposed by Hayes (1989) and adopted in the prosodic hierarchy proposed in Nespor \& Vogel (1986).

As subsequent work questioned the inviolability of Non-Recursivity and Exhaustivity, another form of prosodization for compounds was proposed: recursive PWds (e.g. Peperkamp 1997a, Vigário 2003, Ito \& Mester 2007). This proposal captures the fact that, in many languages, compounds correspond to discrete lexical items resulting from the combination of independent words or from the combination of a stem or an affix with an independent word. However, this approach obscures the conception of prosodic domains as domains of application for specific phonological processes (Vogel 2009, Vigário 2010). In other words, since compounds (recursive PWds) may undergo processes that their members (non-recursive PWds) fail to observe, it must be assumed that both recursive and non-recursive levels can be domains of application for independent phenomena. 
An additional issue with the prosodic representation of compounds is rooted in the fact that, in both approaches to compound prosodization (i.e. in approaches that either adopt or prohibit prosodic recursion), different types of composite structures are often assigned the same prosodic representation, despite differences in their phonological behaviour. In Brazilian Portuguese (BP), for example, it is generally assumed that two types of composite structures have the same prosodic representation (Silva 2010, Toneli 2014): word-word compounds (e.g. guarda-chuva 'umbrella', lit. keep-rain) and stressed affix + word constructions (with either a stressed prefix, e.g. pre-guerra 'pre-war', or a stressed suffix, e.g. cafe-zinho 'coffee.DIM'). Both types of constructions have been represented as recursive PWds or prosodic word groups (PWG - the domain between the PWd and the PPh proposed by Vigário $(2007,2010)$ ) formed by two independent PWds ([[guarda $\left.]_{\mathrm{PWd}}[\text { chuva }]_{\mathrm{PWd}}\right]_{\mathrm{PWd} / \mathrm{PWG}}$, [[pre $\left.]_{\mathrm{PWd}}[\text { guerra }]_{\mathrm{PWd}}\right]_{\mathrm{PWd} / \mathrm{PWG}}$, $\left[[\text { cafe }]_{\text {PWd }}[\text { zinho }]_{\text {PWd }}\right]_{\text {PWd/PWG }}$ ) (Silva 2010 and Toneli $2014,{ }^{2}$ respectively). These analyses are based on the fact that such structures exhibit the same phonological processes (such as vowel raising at the right edge of both elements) and also on the fact that each element in these constructions bears stress. However, what the analyses of BP composite structures fail to consider is that these different types of composite structures present an important contrast with regard to stress patterns, which suggests their prosodization in separate domains.

In this paper, I argue that word-word compounds and stressed affix + word structures are not prosodized in the same domain in BP. Given their differences in stress patterns, I propose that stressed affix + word structures are prosodized recursively in the PWd domain, while word-word compounds are prosodized in an additional domain between the PWd and the PPh. Following Vogel (2008, 2009), I assume that this domain is the composite group (CG). The analysis advanced in this paper thus reconciles two views on the configuration of the prosodic hierarchy that have traditionally been considered to be mutually exclusive: the view that prosodic domains can be recursive, and the view that posits a domain between the PWd and the PPh. I show that these two views are not incompatible, given that prosodic recursion and an additional domain in the prosodic hierarchy serve distinct purposes in the organization of prosodic domains. While prosodic recursion accounts for the attachment of elements to fully formed constructions, the additional domain accounts for the prosodization of composite structures whose phonological behaviour is equivalent neither to $\mathrm{PWds}$ nor to $\mathrm{PPhs}$.

This paper is organised as follows. In Section 2, I summarise different approaches to compound prosodization in order to motivate the (re)introduction of an additional domain into the prosodic hierarchy. In Section 3, I discuss the phonological behaviour of stressed affix + word structures and word-word compounds in BP, focusing on the ways in which they differ. In this section,

[2] Toneli's (2014) analysis of word-word compounds includes only V+N compounds and AdjAdj/N-N demonymic compounds such as franco-canadense 'French Canadian'. 
I also discuss the prosodic mapping of each element in these composite structures, and I compare the phonological behaviour of stressed affix + word structures and word-word compounds with that of independent PWds, unstressed prefixes, and phonological phrases. In Section 4, I review the phonological behaviour of these composite structures in order to argue that word-word compounds are prosodized in the CG, while stressed affix + word structures correspond to recursive PWds. In Section 4, I also discuss the role of recursive nodes in prosodic representation and point to how an approach that considers recursion can be reconciled with an approach that assumes the existence of an additional domain in the prosodic hierarchy.

\section{Composite structures in Prosodic Phonology}

When morphosyntactic structures are mapped onto phonological domains, they are arranged into a limited number of prosodic domains, or constituents. Traditionally, such constituents range from the syllable $(\sigma)$ to the utterance (U) (see the partial prosodic hierarchy in Figure 1) and correspond to domains of application for phonological processes. In early approaches to Prosodic Phonology (Selkirk 1984, 1986; Nespor \& Vogel 1986), each domain must contain at least one instance of the immediately lower domain (i.e. the Exhaustivity principle) and no domain can be contained within a constituent with the same label (i.e. the NonRecursivity principle). In other words, in such approaches, the prosodic hierarchy was regulated by a set of principles that prohibited both the skipping and the repetition of prosodic domains. Exhaustivity and Non-Recursivity were part of the set of principles regulating the prosodic hierarchy known as the Strict Layer Hypothesis (SLH). ${ }^{3}$

Since the first works in Prosodic Phonology, it has been assumed that prosodic constituents circumscribe the domains in which segmental and prominence phenomena apply. Although certain phonological processes may apply in more than one domain, phonological domains should be identified on the basis of particular processes that they exhibit. In general, then, morphosyntactic structures that are mapped onto a given domain (e.g. domain $X$ ) are not expected to undergo the processes that are specific to another domain (e.g. domain $Y$ ). Consider Structure A and Structure B in Figure 2. Both undergo Phonological Process 1. However, the application of Phonological Process 2 is only attested in Structure B. This discrepancy in process application between Structure A and Structure B supports the assumption that they are prosodized in separate domains. This is precisely the situation that, as we will see, holds for the composite constructions under focus: while there is overlap in the segmental processes that word-word compounds and

[3] The two other principles in the SLH are Headedness (one of the elements contained within a given domain must be its head) and Layeredness (the hierarchical order of domains is fixed) (see, e.g., Selkirk 1984, 1986; Nespor \& Vogel 1986). 


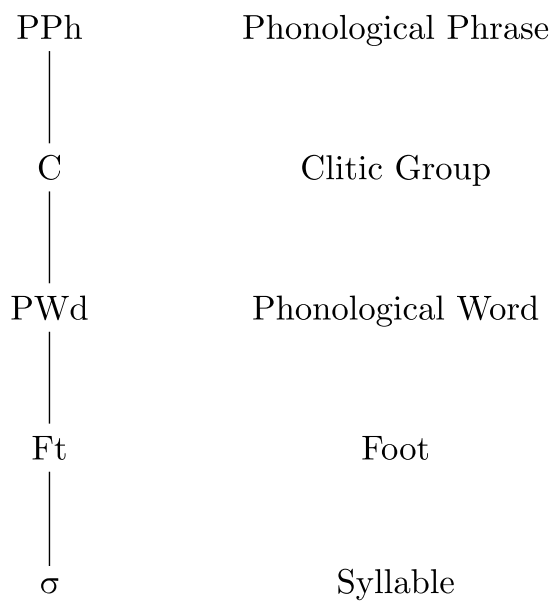

Figure 1

Partial prosodic hierarchy (adapted from Nespor \& Vogel (1986)).

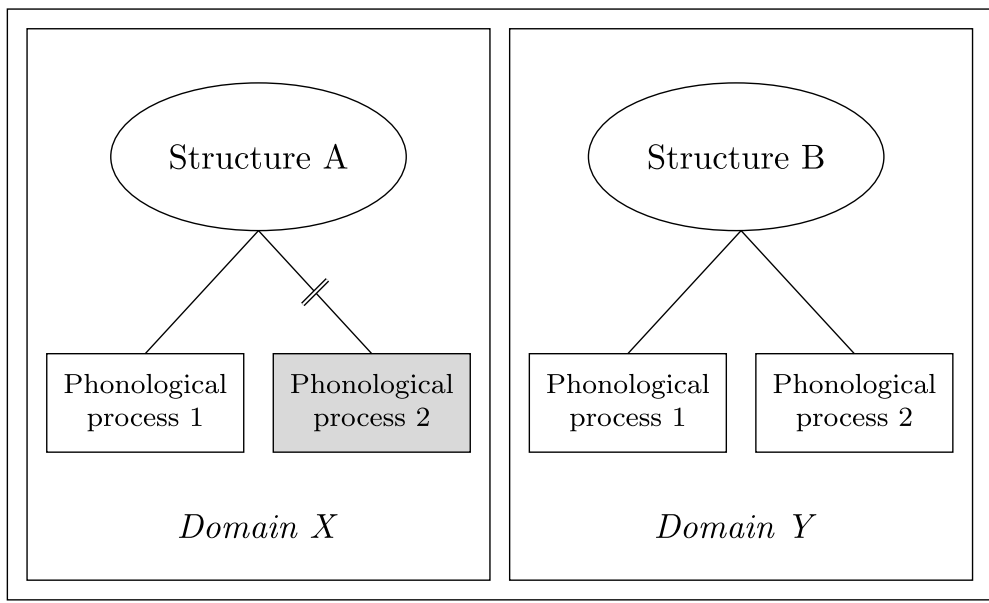

Figure 2

Identification of prosodic domains based on the application of phonological processes.

stress affix + word structures undergo, they differ with respect to the stress patterns that they exhibit.

Approaches to compound prosodization in general assume that prosodic domains differ with regard to the application of phonological processes (Figure 2). These approaches, however, may differ in (a) how they interpret the place of compounds in the prosodic hierarchy and (b) the status that they assign to recursion in prosodic representation. The next subsections describe the main views on the representation of compounds in prosodic theory. 


\subsection{Early approaches}

Early approaches to compound prosodization, such as that of Nespor \& Vogel (1986), were constrained by the SLH, in which domain repetition and domain skipping are not allowed. One possible way to analyse compound prosodization under the SLH is to assume that these structures are prosodized in the domain that immediately dominates the PWd, namely the clitic group (C) (see Figure 1).

This analysis receives support from the observation that compounds are typically the result of the combination of two lexical words, and their phonological behaviour often matches neither that of PWds nor that of PPhs. In this case, compounds would be assigned to the same domain as clitic structures (i.e. clitic + host sequences), and both structures would be formed from independent PWds. For example, if we assume that English compounds correspond to clitic groups, then a compound such as lighthouse and a clitic structure such as help him would have the same prosodic structure $\left(\left[[\text { light }]_{\mathrm{PWd}}[\text { house }]_{\mathrm{PWd}}\right]_{\mathrm{C}},\left[[\text { help }]_{\mathrm{PWd}}[\text { him }]_{\mathrm{PWd}}\right]_{\mathrm{C}}\right)$.

However, clitic structures and compounds often display distinct behaviour within the same language. Nespor \& Vogel (1986) note that, for a language such as Greek, both stem-stem compounds and stem-word compounds display only primary stress (1), but clitic structures contain primary and secondary stresses (2) (examples from Nespor \& Vogel (1986)). In clitic structures, the head PWd (the host) is assigned primary stress, and secondary stress falls on alternate non-final syllables, which means that clitics can be assigned secondary stress. In addition, Greek compounds, but not clitic structures, exhibit a linking vowel (-o-) between their elements.

(1) Compounds in Greek:
(a) kúkla spíti $\rightarrow$ kuklóspito doll house
(b) níxta pulí $\rightarrow$ nixtopúli night bird
(c) níxta filakí $\rightarrow$ nixtofilakí night guard

(2) Clitic structures in Greek:
(a) ðyávase ðyávasè to
ðyávasè mu to read.IMP read.IMP it read.IMP to-me it
(b) yrápse yrápse to yrápse mù to write.IMP write.IMP it write.IMP to-me it

The divergent behaviour between clitic structures and compounds in Greek suggests that these constructions are not prosodized in the same way. Based primarily on stress assignment patterns, Nespor \& Vogel (1986) propose that Greek compounds correspond to PWds ([kuklóspito] $]_{\mathrm{PWd}}$ ), while clitic structures form clitic groups ([[ðyávasè $\left.]_{\mathrm{PWd}}\left[\text { to }_{\mathrm{PWd}}\right]_{\mathrm{C}}\right)$. The fact that compound structures 
present only one stress justifies their representation as a single $\mathrm{PWd}{ }^{4}$ since the PWd is traditionally considered to be the domain where stress is computed crosslinguistically (e.g. Nespor \& Vogel 1986, Selkirk 1996, Peperkamp 1997b).

Earlier analyses in Prosodic Phonology did not include a specific domain for the prosodization of compounds and compound-like structures. In this case, composite structures that behaved differently both crosslinguistically and within a given language were accommodated in different domains of the prosodic hierarchy. In Greek, for example, word-word compounds exhibit two primary stresses and no linking vowel between their elements, which has led to their analysis as PPhs (Nespor \& Ralli 1996). In other languages, the PPh has also been considered as the domain of prosodization for word-word compounds whose phonological behaviour is either compatible with the behaviour of PPhs formed by non-compound lexical words (such as compounds in Italian in which two stresses are detected and a lower mid vowel in the first element is preserved; Nespor \& Ralli 1996) or incompatible with the phonological behaviour of compounds that are assigned to the PWd domain (such as Japanese complex compounds that do not exhibit junctural accent nor rendaku; ${ }^{5}$ Ito \& Mester 2007). ${ }^{6}$

Within this framework, it would be possible to accommodate BP word-word compounds and stressed affix + word structures in distinct prosodic domains, which would be consistent with the observation that these two types of constructions exhibit crucial phonological differences (see Section 3). Since neither of these constructions displays phonological behaviour that is compatible with the behaviour of single PWds, neither of them could correspond to PWds. The solution, then, would be to assign stressed affix + word structures to the clitic group, and word-word compounds to the $\mathrm{PPh}$. However, as will be shown in Section 3, the phonological behaviour of such compounds is not equivalent to that of PPhs, which in turn motivates the prosodization of word-word compounds and phrases in separate domains.

Later developments in Prosodic Theory challenged the existence of the clitic group and, as a result, led to a re-examination of the principles contained within the SLH. The clitic group was criticized for two main reasons, both of them concerning the representation of clitics: (a) both crosslinguistically and within the same language, clitics may show differences in phonological and morphosyntactic behaviour, which suggests that more than one form of prosodization is available to them (Inkelas 1990, Selkirk 1996); (b) clitics are phonologically weak elements, in the sense that their instantiation depends on the existence of a prominent host,

[4] The primary stress position in Greek compounds does not necessarily correspond to the primary stress position in any of their elements. Nespor \& Ralli (1996) point out that stress is fixed in the second element in stem-word compounds in Greek.

[5] See definition and examples of rendaku in the next subsection.

[6] The analysis in Ito \& Mester (2007) is developed in the framework of Optimality Theory (where both Non-Recursivity and Exhaustivity are violable constraints), and thus does not consider the existence of a prosodic domain between the PWd and the PPh (but see discussion on the compatibility between recursion and the inclusion of additional prosodic domains in Section 4). 
which is inconsistent with their representation as independent PWds. Although the re-examination of the SLH principles was motivated by issues concerning the prosodization of clitics, it also had a significant effect on the representation of compounds, as will be discussed in the next subsection.

\subsection{Approaches with NON-RECURSIVITY as a violable constraint}

The weakening of the SLH was most easily accommodated within Optimality Theory (OT) (Prince \& Smolensky 1993/2004). In the OT framework, the problematic principles in the SLH (namely Exhaustivity and Non-Recursivity) are regarded as violable constraints, which means that recursive and non-exhaustive prosodic structures in a given language may emerge depending on how such a language ranks these constraints. Regarding clitic prosodization, it is generally assumed that clitics that are more closely bound to their hosts (by influencing primary or secondary stress assignment in the structure, for example) are assigned to the PWd domain (in the lowest level or recursively), whereas clitics that display freer behaviour are assigned to the PPh (Selkirk 1996, Peperkamp 1997b).

With NON-RECURSIVITY as a violable constraint, the prosodization of compounds was also reconsidered. Evidence from different languages revealed that compound members often preserve their primary stress (Peperkamp 1997a, Vigário 2003) or undergo compound-specific phonological processes (Ito \& Mester 1986). These are indicators that compounds in such languages are not prosodized as simple PWds or as PPhs. Based on the fact that compound words correspond to single lexical items and terminal syntactic nodes, and that compound members behave as independent words (particularly with regard to stress assignment), approaches to compounding in OT generally assume that such structures form recursive PWds (e.g. [[light $\left.]_{\mathrm{PWd}}[\text { house }]_{\mathrm{PWd}}\right]_{\mathrm{PWd}}$ ).

In OT approaches to compound prosodization, then, recursive nodes in the PWd are the domains of application for compound-specific phonological processes. In Japanese, for example, compounds display rendaku (Ito \& Mester 1986, 2007; Kubozono 1995), a process whereby the initial voiceless obstruent of the second compound element becomes voiced ( $3 \mathrm{a}$ and $3 \mathrm{~b}$ ). Rendaku is blocked when there is already a voiced obstruent in the second compound element (3c). The examples in (3) are from Ito \& Mester (1986).

(3) Rendaku in Japanese compounds:

(a) ori + kami $\rightarrow$ origami

fold paper paper-folding

(b) yama + tera $\rightarrow$ yamadera

mountain temple mountain temple

(c) kami + kaze $\rightarrow$ kamikaze, *kamigaze

god wind divine wind 
The observation that rendaku does not apply word-internally or between PWds in PPhs has led to the proposal that Japanese compounds do not correspond to single PWds or PPhs, but to recursive PWds (Ito \& Mester 2007). Japanese compounds, then, are formed by independent PWds which, when combined, constitute a recursive PWd ([[ori $\left.]_{\mathrm{PWd}}\left[\mathrm{gami}_{\mathrm{PWd}}\right]_{\mathrm{PWd}}\right)^{7}$

In other languages, compounds may display variation in phonological behaviour, a property that has been interpreted by some as an indicator of variability in prosodization (Peperkamp 1997a). In Italian, for example, the stressed lower mid vowel in the first element of compounds (such as euro socialista 'Eurosocialist') can be either preserved ([ع]uro) or raised to upper mid ([e]uro) (Peperkamp 1997a).

Peperkamp (1997a) interprets the preservation of lower mid vowels in the first element of Italian compounds as evidence for their prosodization as independent PWds, since such vowels normally occupy stressed positions in the language ([[ع]uro $]_{\mathrm{PWd}}[\text { socialista }]_{\mathrm{PWd}}$ ). On the other hand, the production of such vowels as upper mid indicates that the element in which they are located has lost its PWd stress and thus attaches to the following PWd as a prefix. The resulting prosodic configuration of a compound structure whose first element is realized as upper mid is, then, a recursive PWd: [[e]uro [socialista]PWd $]_{\text {PWd }}$ (Peperkamp 1997a). The fact that s-voicing, a process whereby intervocalic /s/ becomes [z] wordinternally in Italian, is blocked in the second part of the compound regardless of its representation (*euro[z]ocialista) suggests that, in both forms, there is a word boundary between the first and the second element.

Without a specific domain for compound prosodization, compound-specific phenomena (such as rendaku in Japanese) are regarded as processes whose domain of application is a higher PWd (i.e. a recursive level in the PWd domain). However, the assumption that recursive levels can be domains for segmental process application poses a problem for prosodic analysis. Although a particular prosodic domain may require multiple recursive levels, ${ }^{8}$ it is not clear whether all recursive levels can be domains of application for specific phonological processes. ${ }^{9}$ Moreover, the fact that both a given prosodic domain and its recursive

[7] Rendaku respects Lyman's Law, which states that only one voiced obstruent can be found within a morpheme. The examples in (3) may suggest that Japanese compounds correspond to a single PWd, since only one voiced obstruent is found in all of them. However, rendaku is allowed in compounds such as eda-ge 'split hair' (from $e d a+k e$ ) and mizu-zeme 'water torture' (from mizu + seme) (Ito \& Mester 1986). These examples support the idea that there is in fact a PWd boundary between compound elements.

[8] For an analysis of clitic prosodization involving multiple recursive levels, see Peperkamp (1997b). For an analysis of recursive phonological phrasing, see Elfner (2015).

[9] Ito \& Mester $(2007,2009,2013)$ and Martinez-Paricio (2012) argue that certain phonological processes can be associated with minimal (non-recursive) and maximal (highest recursive) prosodic levels. Elfner (2015) also points out that non-minimal levels can be domains for specific processes (see further considerations on phonological processes in non-minimal levels in, e.g., Ito \& Mester $(2009,2013))$. 
nodes can be domains of application for specific phonological processes undermines the definition of prosodic domains as units that result from specific syntaxphonology mapping constraints and in which specific phonological phenomena occur (Vogel 2009, Vigário 2010).

In the case of composite structures in BP, previous analyses (Silva 2010, Toneli 2014) have failed to notice the distinctions in stress patterns between word-word compounds and stressed affix + word structures that support their representation in separate prosodic domains (see Section 3). In Silva's (2010) analysis, which accepts prosodic recursion but discards the existence of a domain between the PWd and the PPh, both word-word compounds (e.g. guarda-chuva 'umbrella', lit. keep-rain) and stressed affix + word structures (e.g. pre-guerra 'pre-war', cidade-zinha 'city.DIM') correspond to recursive PWds. This analysis is rooted particularly in the observation that neither of these constructions phonologically behaves like a single PWd or PPh. As we will see in Section 4, recursion is indeed an option for the representation of composite structures in BP. However, it is precisely the distinctions in stress patterns between word-word compounds and stressed affix + word structures that motivate a recursive representation for stressed affix + word structures and an additional domain between the PWd and the PPh for the representation of word-word compounds.

The problems with recursive representations outlined above, as well as the observation that composite structures undergo particular phonological processes crosslinguistically, have supported the reintroduction of a prosodic domain between the PWd and the PPh (Vigário 2007, 2010; Vogel 2008, 2009). As we will see in the next subsection, while the framework in which the reintroduction of such a domain is couched allows for violations of the Exhaustivity principle, violations of Non-Recursivity are again prohibited.

\subsection{The composite group}

The fact that composite structures display crosslinguistic similarities has led some scholars to reintroduce a domain between the PWd and the PPh to account for their prosodization (Vigário 2007, 2010; Vogel 2008, 2009). In Vogel's (2008, 2009) analysis, this domain is the composite group (CG), which shares certain properties with the clitic group. ${ }^{10}$ The CG comprises cohesive structures that are formed above the PWd, but below the PPh. Thus, CGs encompass constructions that present compositional features, such as certain compounds and certain clitic + host structures.

[10] Vogel's $(2008,2009)$ approach shares many similarities with that of Vigário (2007, 2010). Vigário $(2007,2010)$ argues for the need for a domain between the PWd and the PPh based on the phonological behaviour of composite structures in several languages. In her analysis, this domain is the prosodic word group (PWG). In Vigário's approach, however, the PWG plays no particular role in the prosodization of clitic structures (Vigário 2010: 485). Given the evidence provided in Vogel $(2008,2009)$ that the CG accounts for clitic prosodization, as well as evidence for the prosodization of certain BP clitic structures in the CG (Guzzo 2015), I follow Vogel's proposal that the CG is the domain between the PWd and the $\mathrm{PPh}$. 
As previously mentioned, since the phonological behaviour of composite constructions is often not identical to that of PWds or PPhs across languages, the existence of a particular domain for their prosodization is justified. For example, compounds usually differ from PWds and PPhs with regard to the stress patterns that they exhibit. Stress assignment is regulated by domain-specific algorithms (see, e.g., Nespor \& Vogel 1986), which means that every domain has a particular algorithm for assigning stress to the elements that it contains. In English, compounds and phrases differ with regard to where the primary stress falls: while in compounds it usually falls on the first element (e.g. hót dog), in phrases it falls on the second element (e.g. hot dóg). Following Vogel (2009), this difference is indicative of the prosodization of compounds and phrases in distinct domains. Additionally, the compound hot dog differs from regular PWds in two main ways: (a) it has stress on both of its elements and (b) no type of vowel reduction is attested on the vowel that is not primarily stressed ([hótdòg], but not *[hótdəgg] 'hotdog'; compare with origin [órədzən] $\rightarrow$ original [ərí́dzənəl]).

The CG proposal is contained within an approach to Prosodic Phonology in which violations of the Exhaustivity principle are allowed. Thus, independent syllables (corresponding to clitics) can attach to a PWd directly in the CG, without having to be prosodized as feet and PWds (contra Nespor \& Vogel 1986), which is consistent with the observation that clitics are not usually stressed. However, Vogel's (2008, 2009) approach still regards Non-Recursivity as an inviolable principle. Thus, structures with multiple clitics or a compound with three or more parts are prosodized as non-recursive prosodic constituents (contra, e.g., Peperkamp 1997b).

Based on the assumption that prosodic domains are primarily defined with respect to the particular phonological processes that they exhibit, composite structures whose phonological behaviour does not match that of regular PWds or PPhs in a given language should be assigned to a separate domain. In the case of BP composite constructions, Toneli (2014) indeed proposed that both wordword compounds and stressed affix + word structures are prosodized in a domain between the PWd and the PPh. However, as previously mentioned, Toneli's (2014) proposal did not consider the differences in stress patterns between these two types of composite constructions, a concern that also holds for Silva's (2010) recursive PWd analysis.

In this paper, I demonstrate that the phonological behaviour of word-word compounds in BP is consistent with their prosodization in the composite group, following Vogel (2008, 2009). However, as mentioned in the previous subsection, the analysis of stressed affix + word structures also provides evidence for recursive representations, which departs from Vogel's $(2008,2009)$ proposal. Crucially, the analysis advanced here supports the need for multiple prosodic representations for composite constructions in BP.

In the next section, I discuss the phonological behaviour of composite structures in BP in order to show, in Section 4, how stressed affix + word structures and word-word compounds differ with regard to their prosodic representation. 


\section{Composite StRuCTURES IN BP}

Word-word compounds and stressed affix + word structures in BP are under focus in the present analysis, given their presumed equivalence in phonological behaviour and thus in prosodic representation (Silva 2010, Toneli 2014). As we will see, the differences in stress patterns between these two structures inform our understanding not only about the representation of composite structures in BP, but also about the configuration of the prosodic hierarchy.

In this section, I describe the constructions that are under focus in the present study (Section 3.1). The data presented are based on judgements from five native speakers of BP, all of whom are from the southern state of Rio Grande do Sul and have university degrees. I compare the phonological behaviour of stressed affix + word structures and word-word compounds in BP (Section 3.2) in order to show that, even though they do have similarities, further examination of the stress patterns exhibited by these constructions reveals that they also have important differences. As we will see below, both stressed affix + word structures and word-word compounds undergo vowel raising at the right edge of each of their elements and vowel sandhi processes between their elements. However, only stressed affix + word structures, and not word-word compounds, can be assigned stress according to BP's algorithm for word-level secondary stress.

This difference in phonological behaviour is relevant for determining both the prosodic representation of these structures as a whole and the prosodic representation of each of their elements. The discussion of the representation of each element in these compound structures (Section 3.3) will be supported by additional evidence from their behaviour with respect to a morphosyntactically conditioned phonological phenomenon (namely ellipsis in coordination), in particular for the case of stressed affixes. The data presented in this section support the proposal advanced in Section 4 that word-word compounds and stressed affix + word structures are prosodized in separate domains.

In addition to word-word compounds and stressed affix + word structures, another category of composite construction has been proposed for Portuguese, namely the category of morphological compounds (Villalva 1994). Morphological compounds correspond to composite structures in which at least the first element is a stem; e.g. psico-logia 'psychology', psico-linguistica 'psycholinguistics', and luso-brasileiro 'Luso-Brazilian'. The phonological behaviour of morphological compounds in BP, however, is not uniform: while some of them are phonologically transparent (such as luso-brasileiro, which exhibits similar stress patterns and has the same behaviour with regard to vowel raising as word-word compounds; see Section 3.2), others are phonologically opaque (such as psicologia, in which the final vowel of the first element behaves as an unstressed wordmedial vowel). ${ }^{11}$ As previously mentioned, the present paper focuses only on

[11] While forms such as psicologia have been considered to correspond to simple phonological words, forms of the type neoclassical element + word (e.g. psico-linguistica) have been analysed 
word-word compounds and stressed affix + word structures because these are the composite constructions that have been consistently analysed as having identical phonological behaviour in $\mathrm{BP}$, and thus have been assigned the same prosodic representation.

Before I examine the phonological characteristics of the BP composite structures under analysis, I briefly describe the types of composite structures that are relevant for the present study (Section 3.1).

\subsection{Types of composite structures in BP}

Word-word compounds in (Brazilian) Portuguese can be formed from several distinct combinations of lexical categories (Lee 1997, Moreno 1997, Rio-Torto \& Ribeiro 2012). Table 1 lists examples of word-word compounds in BP (the examples are orthographically transcribed except for stress, which is marked by an acute accent). ${ }^{12}$

The word-word compounds in Table 1 exhibit some differences in terms of their morphosyntactic behaviour. For example, these compounds differ with regard to which element corresponds to the head of the structure: while in some compounds the head is the first element (e.g. sofa cama 'sofa bed'), in others the head is the second element (e.g. sem teto 'homeless'), or there is no identifiable head (e.g. amor perfeito 'pansy'). The position of the head in word-word compounds determines the application of certain morphosyntactic processes, such as pluralisation: the plural suffix $-s$ usually attaches to the head of the structure (e.g. sofa-s cama, sem teto-s), or to both elements if there is no identifiable head (amor-es perfeito-s) (see, e.g., Lee (1997) for a detailed description of the morphosyntactic structure of word-word compounds in BP).

These morphosyntactic differences, however, do not affect the phonological behaviour of word-word compounds in BP (see, e.g., Silva 2010). Unlike in European Portuguese, where word-word compounds can be differentiated based on the application of certain phonological processes (see Vigário 2003), in BP, all types of compounds exemplified in Table 1 undergo the same phonological processes, as will be discussed in the next section. Thus, I assume that such compounds in BP correspond to a single prosodic representation.

as having the same prosodic structure as stressed affix + word structures, even though vowel raising in the final vowel of the neoclassical element is not categorical (unlike what is observed in stressed affix + word structures; see Section 3.2). On the other hand, similarly to inherently stressed prefixes, neoclassical elements in neoclassical element + word structures preserve their lower mid vowel (e.g. [c]tero-sexual 'heterosexual'), indicating that the first element of the compound is prosodized as an independent phonological word (see the discussion in the remainder of this section). For analyses of the prosodic representation of BP morphological compounds, see Guzzo (2015), as well as Silva (2010) and Toneli (2014).

[12] Portuguese also has a number of noun-preposition-noun compounds (e.g. dona de casa 'housewife', lit. owner of house; lua de mel 'honeymoon', lit. moon of honey). Since these compounds do not pattern structurally with word-word compounds in BP, they are not considered in the present study. 


\begin{tabular}{|c|c|c|}
\hline $\begin{array}{l}\text { Word class } \\
\text { of parts }\end{array}$ & $\begin{array}{l}\text { Class } \\
\text { of compound }\end{array}$ & Examples \\
\hline$[\mathrm{N}-\mathrm{N}]$ & $\mathrm{N}$ & $\begin{array}{l}\text { cidáde-satélite } \\
\text { 'satellite city', lit. city satellite }\end{array}$ \\
\hline$[\mathrm{N}-\mathrm{Adj}]$ & (usually) $\mathrm{N}$ & $\begin{array}{l}\text { amór-perféito } \\
\text { 'pansy', lit. love perfect }\end{array}$ \\
\hline [Adj-Adj] & (usually) Adj & $\begin{array}{l}\text { súrdo-múdo } \\
\text { 'deaf mute' }\end{array}$ \\
\hline$[\mathrm{Adj}-\mathrm{N}]$ & (usually) Adj & $\begin{array}{l}\text { bóa-práça } \\
\text { 'pleasant person', lit. good square }\end{array}$ \\
\hline$[\mathrm{V}-\mathrm{N}]$ & (usually) $\mathrm{N}$ & $\begin{array}{l}\text { guárda-róupa } \\
\text { 'wardrobe', lit. keep clothing }\end{array}$ \\
\hline$[\mathrm{V}-\mathrm{V}]$ & $\mathrm{N}$ & $\begin{array}{l}\text { córre-córre } \\
\text { 'haste', lit. run run }\end{array}$ \\
\hline$[\mathrm{Adv}-\mathrm{Adj}]$ & (usually) $\mathrm{N}$ & $\begin{array}{l}\text { sémpre-víva } \\
\text { 'evergreen (plant)', lit. always alive }\end{array}$ \\
\hline [Prep-N] & (usually) $\mathrm{N}$ & $\begin{array}{l}\text { sém-této } \\
\text { 'homeless', lit. without roof }\end{array}$ \\
\hline
\end{tabular}

Table 1

Word-word compounds in BP.

The other construction under present focus is stressed affix + word structures. These structures emerge from the attachment of an inherently stressed prefix or suffix to a fully formed word. Table 2 provides examples of composite structures with stressed affixes.

\begin{tabular}{ll|l}
\hline \multicolumn{2}{c|}{ Stressed prefix + word } & \multicolumn{2}{l}{ Word + stressed suffix } \\
\hline pré-guérra & 'pre-war' & cidáde-zínha 'city.DIM' \\
pós-modérno & 'post-modern' & suáve-ménte 'smoothly' \\
éx-presidénte & 'ex-president' & \\
více-reitór & 'vice-dean' & \\
ánti-capitalísmo & 'anti-capitalism' & \\
\hline
\end{tabular}

Table 2

Inherently stressed affix + word structures in BP.

While BP has many inherently stressed prefixes, the number of inherently stressed suffixes is very limited. It is generally assumed that suffixes fall within 
the regular stress domain in BP. Primary stress in BP is assigned within a threesyllable window at the right edge of the word, and the language shows a strong tendency toward trochaic rhythm (e.g. ativ-idáde 'activity', marmel-áda 'marmalade', jornal-ísmo 'journalism') (Bisol 1992, Hermans \& Wetzels 2012). It may seem, thus, that constructions with the suffixes $-(z)$ inho and -mente receive stress according to BP's primary stress algorithm. However, evidence from vowel quality suggests otherwise. In BP, lower mid vowels are found only in primarily stressed positions. While such vowels in the stem raise to upper mid with the attachment of regular suffixes (e.g. g[ó]lpe $\rightarrow$ g[o]lpe-ádo 'strike $n$, struck') (Wetzels 1992; see also Câmara 1970), the attachment of inherently stressed suffixes (e.g. -(z)inho and -mente) does not affect the quality of the stem

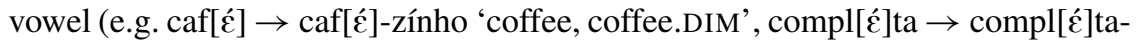
ménte 'complete, completely'). Therefore, this indicates that there is a prosodic boundary between suffixes such as -(z)inho and -mente and the preceding stem. Since stress is realized on both the stem and the suffix in such structures, these suffixes are usually regarded as inherently stressed and non-incorporating (i.e. they are not incorporated into the PWd of the stem to which they attach) (Lee 2013, Schwindt 2013).

When morphosyntactic structures are mapped onto the prosodic hierarchy, they undergo domain-specific phonological processes (Nespor \& Vogel 1986, Vogel 2009). When comparing two (or more) types of linguistic structures, then, their phonological behaviour provides evidence as to the prosodic domain to which they are assigned. In the next subsection, I describe the phonological behaviour of word-word compounds and stressed affix + word structures. I show that although these two composite constructions display similarities in phonological behaviour (with regard to vowel raising and vowel sandhi), their stress patterns differ, which supports their prosodization in separate domains.

\subsection{Phonological behaviour of composite structures}

\subsubsection{Phonological similarities between composite structures: Vowel raising and vowel sandhi}

Word-word compounds and stressed affix + word structures overlap in the application of phonological processes in BP. Both undergo vowel raising at the right edge of each of their elements and vowel sandhi processes at the juncture between the two elements.

Vowel raising, a process whereby unstressed upper mid vowels /e, o/ become $[\mathrm{i}, \mathrm{u}]$, applies categorically in word-final position in standard BP dialects (Leite \& Callou 2002). While vowel raising applies word-finally in PWds forming phonological phrases (4), it is also observed in final position in word-word compound members (5) and in stressed affix + word structures (6). 
(4) Vowel raising in phonological phrases:

(a) meníno boníto $\rightarrow$ menín[u] bonít[u] boy beautiful beautiful boy

(b) génte fascinánte $\rightarrow$ gént[i] fascinánt[i] people fascinating fascinating people

(5) Vowel raising in word-word compounds:

(a) prónto socórro $\rightarrow$ prónt[u] socórr[u] ready help emergency room

(b) cidáde satélite $\rightarrow$ cidád[i] satélit[i] city satellite satellite city

(6) Vowel raising in stressed affix + word structures:
(a) více presidénte $\rightarrow$ víc[i] presidént[i] vice president
(b) suáve ménte $\rightarrow$ suáv[i] mént[i] soft adv. suf. softly

However, at the right edge of stems that combine with non-inherently stressed suffixes beginning with a consonant, vowel raising does not apply (7). ${ }^{13}$ Vowel raising also fails to apply in unstressed monosyllabic prefixes (8) (Schwindt 2001). ${ }^{14}$

(7) Blocking of vowel raising in stem + incorporating suffix:
(a) promete + dor $\rightarrow$ promet[e]dór, *promet[i]dór promise noun suf. person who makes a promise
(b) perde + dor $\rightarrow$ perd[e]dór, *perd[i]dór lose noun suf. loser

(8) Blocking of vowel raising between unstressed monosyllabic prefix + word:
(a) re + fazér $\rightarrow$ r[e]-fazér, *r[i]-fazér
re do
(b) co + produzír $\rightarrow$ c[o]-produzír, *c[u]-produzír co produce

[13] Word-internally, vowel raising is highly constrained. Unstressed vowels in pretonic position variably raise if there is a high vowel in the following syllable (e.g. tossír $\rightarrow \mathrm{t}[\mathrm{u}] \mathrm{ssír}$ 'to cough', boníto $\rightarrow$ b[u]níto 'beautiful') or in specific word families (e.g. s[u]sségo, s[u]ssegár, s[u]ssegádo 'rest, to rest, rested') (Bisol 1981, 2009; Oliveira 1992).

[14] It should be noted that the unstressed prefixes des- and en- have been shown to exhibit vowel raising categorically across dialects of BP. The application of vowel raising in such prefixes has been accounted for based on lexical conditioning and phonotactic environment, not prosodic structure (see, e.g., Battisti 1993; also Schwindt 2001, 2008). 
Vowel sandhi processes also optionally occur between the elements in both word-word compounds and stressed affix + word structures in BP. The sandhi processes that apply in these constructions are, according to the labels found in the literature about Portuguese phonology, degemination (i.e. a vowel deletes when followed by an identical vowel) and elision (i.e. a vowel deletes when followed by a distinct vowel) (Abaurre 1996, Tenani 2002, Bisol 2003, Gayer 2014). ${ }^{15}$ Degemination is exemplified in (9) for word-word compounds and in (10) for stressed prefix + word structures.

(9) Degemination in word-word compounds:
(a) péixe espáda $\rightarrow$ pèix[i]spáda
fish sword sword fish
(b) báte estáca $\rightarrow$ bàt[i]stáca
hit.V pole pile driver

(10) Degemination in stressed prefix + word structures:

(a) více inspetór $\rightarrow$ vìc[i]nspétor vice inspector

(b) súpra auxílio $\rightarrow$ sùpr[a]uxílio supra aid

Elision is exemplified in (11) for word-word compounds and in (12) for stressed prefix + word structures. Note that elision in BP applies more frequently when there is a low vowel $(/ \mathrm{a} /)$ in the first position of the vowel sequence.

(11) Elision in word-word compounds:
(a) água oxigenáda $\rightarrow$ àgu[o]xigenáda water oxygenated hydrogen peroxide
(b) empúrra empúrra $\rightarrow$ empùrr[i]mpúrra push.V push.V constant shoving

(12) Elision in stressed affix + word structures:

(a) ínfra estrutúra $\rightarrow$ ìnfr[i]strutúra infra structure

(b) súpra eleitorádo $\rightarrow$ sùpr[e]leitorádo supra electorate

Degemination and elision also apply at the juncture of two words within a phonological phrase in BP (13).

[15] Diphthongization is another vowel sandhi process found in BP. However, this phenomenon will not be discussed in the present study, as it may occur both word-internally and phrase-internally, and thus does not help to differentiate among prosodic structures in the language. 
(13) Sandhi processes within phonological phrases:

(a) cása amaréla $\rightarrow$ càs[a]maréla house yellow yellow house

(b) cása organizáda $\rightarrow$ càs[o]rganizáda house organized organized house

Importantly, the application of these juncture processes is constrained by position of word stress and position of phrasal stress (Abaurre 1996, Tenani 2002, Bisol 2003). Within a single PPh, while sandhi processes cannot apply when the target vowels are both stressed (e.g. sofá útil $\rightarrow$ *sofútil 'useful sofa'), degemination is possible when a stressed vowel in the first element is followed by an identical unstressed vowel (e.g. sofá agradável $\rightarrow$ sofàgradável 'nice sofa'). The composite structures under focus cannot be compared with phonological phrases with respect to the (non-)application of sandhi processes involving two stressed vowels, or a stressed vowel followed by an identical unstressed vowel, given that there are no word-word compounds or stressed affix + word structures with such profiles.

However, it is possible to compare composite structures and two-word phrases with regard to the application of sandhi processes by examining structures whose second element starts with stressed vowels. For both two-word phrases (14) and word-word compounds (15), sandhi processes are blocked if the second vowel is stressed. ${ }^{16}$ In both (14) and (15), the blocking of degemination is exemplified in (a) while the blocking of elision is exemplified in (b). (15c) additionally exemplifies the blocking of elision.

(14) Blocking of sandhi in phrases where the second vowel is stressed:

(a) cóisa ágil $\rightarrow$ cóisa ágil, *coiságil thing agile agile thing

(b) cóma úvas $\rightarrow$ cóma úvas, *comúvas eat.IMP grapes

(15) Blocking of sandhi in word-word compounds where the second vowel is stressed:

(a) torcída álvo $\rightarrow$ torcída álvo, *torcidálvo group of fans target target group of fans

(b) bába óvo $\rightarrow$ bába óvo, *babóvo drool.v egg adulator

[16] I cannot find any examples of stressed prefix + word structures in which the prefix ends with a vowel, the host word starts with a stressed vowel, and there is a context for degemination or elision. For the hypothetical examples that I could think of, the native speakers consulted reject both degemination and elision: súpra álvo $\rightarrow{ }^{*}$ suprálvo 'supra target', súpra ćlo $\rightarrow$ *suprélo 'supra link'. The intuition of these speakers is that these sandhi processes will also be blocked if the main stress of the phonological phrase where the stressed affix + word structures is inserted is not on the composite structure, similarly to what is observed in word-word compounds (see (17)). 
(c) pédra ímã $\rightarrow$ pédra ímã, *pedrímã stone magnet magnet

However, such sandhi processes can apply in longer phrases where the second vowel is not the primarily stressed vowel in the construction (16) (Abaurre 1996, Tenani 2002, Bisol 2003). These processes, though, are blocked in word-word compounds that are followed by a fully formed word in the same phonological phrase (17), which is also observed in equivalent structures in European Portuguese (Vigário 2010).

(16) Sandhi in phrases where the second vowel is not the primarily stressed vowel in the construction:

(a) cóisa ágil assím $\rightarrow$ coisàgil assím thing agile like-this agile thing like-this

(b) cóma úvas madúras $\rightarrow$ comùvas madúras eat.IMP grapes ripe eat.IMP ripe grapes

(17) Blocking of sandhi in word-word compounds where the second vowel is not the primarily stressed vowel in the construction:
(a) torcída álvo suéca $\rightarrow$ *torcidàlvo suéca group of fans target Swedish Swedish target group of fans
(b) bába óvo maçánte $\rightarrow$ *babòvo maçánte drool.v egg boring boring adulator
(c) pédra ímã boníta $\rightarrow$ *pedrìmã boníta stone magnet beautiful beautiful magnet

The examples above show that, while stressed affix + word structures and word-word compounds pattern together with respect to the application of sandhi processes, they both differ from phonological phrases formed by non-compounds (see observation on stressed affix + word structures in footnote [16]). Similarly to what has been discussed for vowel raising, the behaviour of these composite structures is also different from that of non-compounds and unstressed prefixes with regard to sandhi. Word-internally, such sandhi processes do not occur. Although words with a word-internal sequence of two identical vowels are rare in $\mathrm{BP},{ }^{17}$ contexts of hiatus involving two distinct vowels are relatively more frequent. In this case, words such as baobá 'Adansonia tree' and maestría 'mastership' are not produced as *bobá or *mestría. Although elision does not apply wordinternally, it is possible for some contexts of hiatus to be resolved through

[17] Among the lexical items that have an orthographic word-internal sequence of identical vowels in $\mathrm{BP}$, a few seem to undergo degemination (e.g. álcool $\rightarrow$ álc [o]l 'alcohol' and compreensão $\rightarrow$ compr[e]nsão 'understanding $n$.'). Given the categorical non-application of word-internal degemination in other lexical items (e.g. apreensão $\rightarrow *$ apr[e]nsão 'aprehension', niilísta $\rightarrow$ *n[i]lista 'nihilist'), it is likely that the items that exhibit degemination are stored in the BP lexicon with only one vowel. 
diphthongization (e.g. maestría $\rightarrow$ ma[j]stría). In the case of unstressed prefixes, degemination is blocked (e.g. re-erguér $\rightarrow$ *rerguér 'to rebuild', co-organizár $\rightarrow$ * corganizár 'to co-organise'). ${ }^{18}$

In addition to undergoing both vowel raising and vowel sandhi processes, the elements in word-word compounds and stressed affix + word structures have primary stress. Specifically, fully formed words in these constructions maintain the stress pattern that they exhibit when in isolation (e.g. guárda + chúva = guárda-chúva). As previously mentioned, the prefixes and suffixes involved in composite structures are inherently stressed. Furthermore, lower mid vowels are preserved in both fully formed words and stressed affixes. Example (18) exemplifies lower mid vowel preservation in word-word compounds, in stressed prefix + word structures, ${ }^{19}$ and in word + stressed suffix structures, respectively.

(18) Lower mid vowel preservation in word-word compounds and stressed affix + word structures:
(a) bóta + fóra $\rightarrow$ bóta fóra
(b) pré + escóla $\rightarrow$ pré escóla
pre school
(c) compléta + ménte $\rightarrow$ compléta ménte complete adv. suf. completely

The fact that the elements in these composite constructions exhibit vowels that are found only in primarily stressed syllables has been considered to be indicative of the status of each element as an independent PWd (Silva 2010, Toneli 2014; see also Schwindt 2001 for prefixes). Additionally, the second element in word-word compounds and stressed prefix + word structures can variably exhibit initial stress (i.e. a high tone on the initial syllable) and emphatic stress (i.e. a high tone on any pretonic syllable), which further suggests the existence of a PWd boundary between the elements in these constructions (Toneli, Vigário \& Abaurre (2014); see Vigário \& Fernandes-Svartman (2010) for further discussion on tonal patterns in BP compounds).

In this subsection, we have seen that word-word compounds and stressed affix + word structures behave similarly with respect to vowel raising and vowel sandhi processes. While both composite constructions behave similarly to strings of PWds forming phrases with regard to vowel raising, vowel sandhi is more

[18] There is no context for elision involving unstressed prefixes because no unstressed prefix ends with /a/. In cases where the unstressed prefix vowel is followed by a vowel of different quality, the hiatus is maintained (e.g. re-analisár $\rightarrow$ re-analisár, *ranalisár, *rjanalisár 'to re-analyse').

[19] Stressed prefixes such as pré 'pre', pós 'post', pró 'pro' also have unstressed counterparts, in which a higher mid vowel is present (e.g. pr[e]ámbulo 'preamble', p[o]stergár 'to postpone'). Such forms with unstressed prefixes have been analysed as lexicalized and thus correspond to simple PWds (see, e.g., Schwindt 2001). 
constrained in word-word compounds and stressed affix + word structures than it is in phrases. We have also seen that the elements in both types of constructions exhibit stress and preserve lower mid vowels. Based on these phenomena, it appears that word-word compounds and stressed affix + word structures do not differ from each other with regard to phonological behaviour. We may thus be tempted to conclude that such constructions have a single form of prosodization. However, in the next subsection, I show that word-word compounds and stressed affix + word structures exhibit distinct stress patterns. Since prosodic domains are often associated with specific prominence patterns, such a distinction is important for determining the prosodic representation of these composite structures in BP.

\subsubsection{Phonological differences between composite structures: Stress patterns}

As discussed in the previous subsection, each element in word-word compounds and stressed affix + word structures is stressed, which suggests that both types of composite structures are formed from independent PWds. However, word-word compounds differ from stressed affix + word structures with regard to the stress patterns that can occur on the first element, which indicates that the domains in which such PWd combinations occur are different. As I show below, the presence of stress patterns that target composite structures in BP does not entail any changes in vowel quality (i.e. lower mid vowels are preserved), which is an indication that they apply after primary stress is assigned to each of the elements in the constructions. As we will see in Section 4, the distinctions in stress patterns between the constructions under focus suggest the need for a more articulated prosodic hierarchy.

Before discussing the crucial difference in stress patterns between word-word compounds and stressed affix + word structures, it is important to acknowledge that these two types of composite structures share some similarities in this respect. Specifically, both word-word compounds and word + stressed suffix structures optionally exhibit stress retraction in the context of a clash. Examples (19) and (20) illustrate clash resolution in word-word compounds and word + stressed suffix structures, respectively. Stress retraction due to clash is not observed in stressed prefix + word structures, since no prefix in BP has final stress.

(19) Clash resolution in word-word compounds:

(a) amór próprio $\rightarrow$ ámor próprio

love self self-love

(b) sofá cáma $\rightarrow$ sófa cáma

sofa bed

(c) além már $\rightarrow$ álem már

beyond sea overseas

(20) Clash resolution in word + stressed suffix structures:

(a) calór zínho $\rightarrow$ cálor zínho

heat dim. suf. heat.DIM 
(b) reál ménte $\rightarrow$ réal ménte

real adv. suf. really

(c) totál ménte $\rightarrow$ tótal ménte

total adv. suf. totally

Stress retraction due to clash has been previously identified as a phonological phrase phenomenon in BP (Sandalo \& Truckenbrodt 2003, Gravina \& FernandesSvartman 2013). In other words, a word with final stress will exhibit stress retraction if the following word has initial stress and is in the same PPh (21). The examples in (19) and (20) indicate that stress retraction due to clash is also observed in composite structures.

(21) Clash resolution in phonological phrases:

(a) café quénte $\rightarrow$ cáfe quénte coffee hot hot coffee

(b) contóu túdo $\rightarrow$ cóntou túdo told.3SG everything

The crucial difference between word-word compounds and stressed affix + word structures is that in the latter (i) stress on the first element can move to the left even if there is no stress clash in the structure (particularly for word + stressed suffix structures; see (22)) and (ii) stress on the first element can not only retract, but also advance ${ }^{20}$ one syllable (this is possible for both word + stressed suffix structures (23) ${ }^{21}$ and stressed prefix + word structures (24)).

(22) Stress retraction on the first element of word + stressed suffix structures:

(a) medída zínha $\rightarrow$ médida zínha measure dim. suf. measure.DIM

(b) compléta ménte $\rightarrow$ cómpleta ménte complete adv. suf. completely

(c) seréna ménte $\rightarrow$ sérena ménte calm adv. suf. calmly

(23) Stress advancement on the first element of word + stressed suffix structures:

(a) ácido zínho $\rightarrow$ acído zínho acid dim. suf. acid.DIM

[20] Further research is required to carefully probe whether stress retraction and stress advancement are constrained in the same way as emphatic stress in BP (as reported in Toneli et al. (2014)). However, a preliminary examination of the data suggests that this is not the case, at least for stress advancement: while stress advancement displaces prominence to a post-tonic syllable, emphatic stress is not observed in post-tonic position.

[21] The examples in (23) are not possible in Lee's (2013) analysis of diminutive structures in BP. The example that Lee uses is pérola-zínha 'pearl.DIM' (which should not become *perólazínha). However, while native speakers' judgements were uniform for the words listed in (23), they were less consistent for words such as pérola-zínha. Thus, it is possible that stress advancement is constrained by vowel quality. This issue, however, requires further examination. 
(b) árvore zínha $\rightarrow$ arvóre zínha

tree dim. suf. tree.DIM

(c) prática ménte $\rightarrow$ pratíca ménte practical adv. suf. practically

(24) Stress advancement on the first element of stressed prefix + word structures:

(a) súper mercádo $\rightarrow$ supér mercádo super market

(b) híper atívo $\rightarrow$ hipér atívo hyper active

(c) více reitór $\rightarrow$ vicé reitór vice dean

(d) ánti tetánico $\rightarrow$ antí tetánico anti tetanic

The behaviour of stressed affix + word structures in the examples in (22-24) is identical to the behaviour of simple PWds (stem + non-inherently stressed suffixes) with respect to secondary stress assignment. In simple PWds, primary stress is constrained to one of the last three syllables in the domain, and, in words with an odd number of syllables to the left of the stressed one, two distinct patterns of secondary stress assignment are observed (Collischonn 1994, Lee 2002, Abaurre et al. 2006): secondary stress can either follow an alternating pattern (e.g. deslizaménto 'landslide') or be assigned to the leftmost syllable in the word, which thus results in a lapse (e.g. dèslizaménto). The examples in (2224) indicate that stress on the first element of stressed affix + word structures is optionally adjusted according to BP's algorithm for secondary stress assignment.

As noted above, both elements in stressed affix + word structures have already been assigned stress when they form a composite structure (e.g. compléta + ménte = compléta-ménte). Thus, although adjustment of the position of stress on the first element is possible, there is an overall preference for maintaining its original position, unless there is clash (e.g. café + zínho = cáfe-zínho). It should also be noted that, in stressed prefix + word structures where prominence in the prefix moves, there seems to be a preference for stressing heavy syllables. For example, a form such as supér-mercádo (from súper-mercádo 'supermarket') seems to be more likely than a form such as vicé-reitór (from více-reitór 'vice dean'), given that the final syllable in super is heavy. ${ }^{22}$

On the other hand, stress on both elements of word-word compounds is fixed except in the context of clash, where it will move to the left (in the first element). This means that, unlike in stressed affix + word structures, it cannot move to

[22] This preference for stressing heavy syllables, however, has not been observed for secondary stress assignment in non-composite BP words (see, e.g., Collischonn 1994). 
the right in the first element when there is a two-syllable lapse between the two stressed syllables in the construction (25).

(25) Blocking of stress advancement on the first element of word-word compounds:
(a) prónto socórro $\rightarrow$ *prontó socórro
ready help
(b) pórta bandéira $\rightarrow$ *portá bandéira holder flag flag holder
(c) açúcar mascávo $\rightarrow$ *açucár mascávo sugar brown brown sugar

Therefore, the stress patterns observed in structures with a stressed affix and word-word compounds are different. While word-word compounds undergo stress retraction in clash environments, structures with a stressed affix can be assigned prominence in the same fashion as simple PWds (i.e. according to BP's algorithm for secondary stress in PWds).

As noted in some of the examples above, neither stress retraction (in wordword compounds and word + stressed suffix structures) nor stress movement due to secondary stress assignment (in constructions with a stressed affix) causes lower mid vowels to raise (26).

(26) Preservation of lower mid vowels after stress retraction (a) or movement (b):
(a) chapéu cóco $\rightarrow$ chápeu-cóco, *chápeu-cóco hat coconut bowler hat
(b) compléta ménte $\rightarrow$ cómpleta-ménte, *cómpleta-ménte complete adv. suf. completely

As previously discussed, lower mid vowels are associated with primarily stressed syllables in Portuguese (Câmara 1970, Wetzels 1992), and, in derived contexts in which the added suffix is assigned stress, lower mid vowels in the stem become upper mid vowels (27).

(27) Neutralisation of lower mid vowels in unstressed positions:
(a) bóla $\rightarrow$ boláda
ball strike with ball
(b) fébre $\rightarrow$ febríl
fever feverish

The fact that elements in word-word compounds and stressed affix + word structures preserve their lower mid vowels even after stress moves is indicative that such elements correspond to independent PWds, consistent with previous analyses (Silva 2010, Toneli 2014; see also Schwindt 2001 for prefixes). The next 
subsection further discusses the prosodic status of the elements in both wordword compounds and stressed affix + word structures in light of their phonological behaviour.

\subsection{The prosodic status of compound members: Additional evidence from ellipsis in coordination}

The description of the phonological behaviour of BP composite structures provided in the previous section showed that word-word compounds and stressed affix + word structures have several similarities: (a) each of the elements in both types of constructions bears stress, (b) lower mid vowels, which are associated with primarily stressed syllables in BP, are preserved, even when the stress in the element moves, and (c) unstressed vowels in final position in the first element undergo the same segmental processes, namely vowel raising and vowel sandhi. These characteristics of both types of composite constructions suggest that each element in such constructions forms a separate PWd.

On the other hand, the independent PWd status of stressed affixes appears to be challenged given that structures containing such elements can be assigned secondary stress according to BP's secondary stress algorithm. The fact that such constructions are targeted by a rhythmic pattern that targets non-compounds could indicate that the combination of a word and a stressed affix instead forms a constituent with no internal boundaries. In other words, the elements in stressed affix + word structures may not correspond to independent PWds, but may instead appear to combine into a single PWd.

Evidence from an additional phenomenon arbitrates between these two options for the prosodization of stressed affixes. The phenomenon in question is ellipsis in coordination, whereby the first instance of a given item can be omitted in coordinate constructions formed by PWds (see, e.g., Vigário \& Frota 2002). In BP composite constructions, this phenomenon is observed in both word + stressed suffix structures and stressed prefix + word structures (28) (see, e.g., Schwindt 2001). Specifically, in coordinate structures with two identical stressed suffixes, the first suffix can be omitted (28a), ${ }^{23}$ while in coordinate structures with two stressed prefixes, the first instance of the repeated lexical word can be omitted (28b).

[23] Ellipsis does not occur with the stressed suffix -zinho (e.g. cafe-zinho e cha-zinho $\rightarrow *$ cafe $e$ cha-zinho 'coffee.DIM and tea.DIM'). This may be due to one of two possibilities: (a) this suffix cannot take scope over the entire structure or (b) its omission has semantic consequences. In either case, the blocking of ellipsis with -zinho does not seem to be influenced by prosodic factors. In European Portuguese, diminutive suffixes in coordinate structures behave in the same way as BP diminutive suffixes. Vigário \& Frota (2002) propose that ellipsis is blocked with such suffixes so as to avoid ambiguity. 
Ellipsis in coordinated stressed affix + word structures:

(a) linda-mente e suave-mente $\rightarrow$ linda e suave-mente beautifully and softly

(b) pre-cirurgia e pos-cirurgia $\rightarrow$ pre e pos-cirurgia pre-surgery and post-surgery

Ellipsis in coordination also targets stressed affix + word structures in European Portuguese (Vigário \& Frota 2002). Given that only structures formed by two PWds are subject to this phenomenon, ellipsis is blocked in structures with unstressed prefixes (29a) and incorporating suffixes (29b), which is also observed in BP. The examples in (29) are from Vigário \& Frota (2002).

(29) Blocking of ellipsis in coordinated structures with unstressed prefixes (a) and incorporating suffixes $(b)$ :

(a) des-fazer e re-fazer $\rightarrow *$ des e re-fazer un-do and re-do

(b) isola-mento e revesti-mento $\rightarrow$ *isola e revesti-mento insulation and coating

Although stressed affix + word structures undergo ellipsis in coordination, which is consistent with the observation that both constructions are formed from PWds, in word-word compounds, this process seems to be blocked. Example (30) illustrates the blocking of ellipsis with coordinated word-word compounds in which the same PWd appears in both structures.

Blocking of ellipsis in coordinated word-word compounds:

(a) guarda-roupa e guarda-chuva $\rightarrow$ *guarda-roupa e chuva wardrobe and umbrella

(b) sempre-viva e agua-viva $\rightarrow$ *sempre e agua-viva evergreen and jellyfish

In the case of word-word compounds, there are contexts where we might expect ellipsis to be more likely to occur in BP. For example, Vigário \& Frota (2002) reported that V-N compounds can undergo ellipsis in European Portuguese: coordinate constructions such as corta-papeis e pisa-papeis "paper knives and paper weights' can be produced as corta e pisa-papeis (Vigário \& Frota 2002). However, ellipsis in V-N compounds does not seem to be possible in BP. The native speakers who were consulted pointed out that the constructions that result from ellipsis involving coordinate V-N compounds (31) sound odd. ${ }^{24}$

[24] An anonymous reviewer pointed out that a sentence such as Você trouxe o corta ou o pisapapeis? 'Did you bring the paper knives or the paper weights?' should be possible in both European and Brazilian Portuguese. It seems to me that ellipsis is indeed possible here, but only on condition that the sentence corresponds to a confirmation question (i.e. the speaker wants to confirm whether or not he/she heard the correct compound). In that case, ellipsis in 
Blocking of ellipsis in coordinated $V$-N compounds in BP:

(a) tira-manchas e tira-odores $\rightarrow$ *tira-manchas e odores remove-stains $(n)$ and remove-odours (n)

(b) lava-roupa e seca-roupa $\rightarrow$ *lava e seca-roupa wash-clothing (n) and dry-clothing (n)

In addition, the native speakers agree that, if they heard such constructions with ellipsis (e.g. tira-manchas e odores and lava e seca-roupa; see (31)), they would assume that each of them refers to a single entity. Thus, it seems that these constructions are either interpreted by native speakers as phrases or as new compound forms. This is consistent with what has been observed in other Romance languages which allow ellipsis when there is a coordination relation between two V-N compounds. In Italian, for example, constructions such as lavaasciuga biancheria 'washer, drier' (from lava-biancheria, asciuga-biancheria, lit. wash-clothing, dry-clothing) have been analysed as new compounds formed from recursion (Bisetto 2010).

Therefore, in the case of BP word-word compounds, it appears that ellipsis in coordination is blocked due to semantic factors, not prosodic factors. Each wordword compound corresponds to an independent lexical item and conceptual unit. Although each of its elements behaves phonologically as an independent PWd, the word-word compound as a whole corresponds to a semantic unit, which constrains the application of ellipsis in coordination. If prosodic factors conditioned the application of ellipsis in word-word compounds, such constructions should in fact undergo this phenomenon.

Unlike what has been observed for V-N compounds in Italian (Bisetto 2010), the application of ellipsis in stressed affix + word structures in BP does not result in a new composite structure. This conclusion is based on the fact that elements can be inserted within the coordinate construction. For example, the construction in (28b) provided above may be produced as na pre e na poscirurgia 'in-the pre and in-the post-surgery' (e.g. Você precisa de cuidados na pre e na pos-cirurgia 'You need care in-the pre and in-the post-surgery'), with both composite structures included in prepositional phrases. Therefore, the evidence from ellipsis in coordination does not challenge the proposal that stressed affix + word structures are formed by PWds.

In addition to displaying ellipsis in coordinate structures, stressed affixes in BP show rather independent morphosyntactic behaviour. Stressed prefixes can appear independently in sentences (32), which means that they may correspond to terminal syntactic nodes.

sentences such as Você disse sempre ou agua-viva? 'Did you say evergreen or jellyfish?' (see (30)) and Você disse des ou re-fazer? 'Did you say undo or redo?' (see (29a)) should also be possible. 


\section{(32) (a) Ela ainda pensa no ex.}

'She still thinks about the ex' (e.g. ex-boyfriend, not ex-boss)

(b) Falei com o presidente e o vice.

'(I) spoke with the president and the vice' (e.g. vice-president, not vice-dean)

This property of stressed prefixes has been proposed to be additional evidence for their status as independent PWds (Schwindt 2001), even though their syntactic independence is limited. In (32a), ex can only be interpreted as ex-boyfriend (or any kind of romantic partner), but not as ex-boss or ex-colleague, for example, even if there is no reference to boyfriend in the context. This is an indication that the meaning of this prefix has been lexicalized. In (32b), vice must be interpreted as vice-president, since presidente 'president' functions as the referent in this case.

\subsection{Summary}

As described in Section 3.2, the phonological behaviour of each element in wordword compounds and stressed affix + word structures is consistent with their classification as independent PWds. As seen in Section 3.3, additional evidence for the PWd status of stressed prefixes stems from the finding that stressed affix + word structures undergo ellipsis in coordination. These observations are consistent with previous analyses which propose that each element in word-word compounds and stressed affix + word structures corresponds to an independent PWd (Schwindt 2001, Silva 2010, Toneli 2014). Figure 3 thus shows that wordword compounds and stressed affix + word structures have the same internal representation; however, the prosodic structures are not yet specified with respect to which prosodic domain $(D)$ the elements in these constructions attach to.

(a) word-word compound

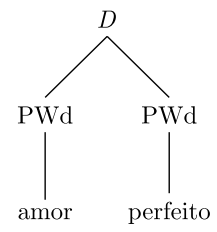

(b) stressed prefix + word

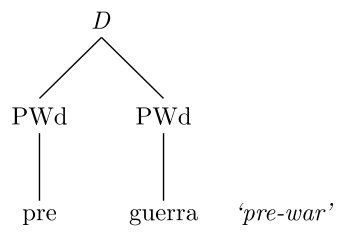

(c) word + stressed suffix

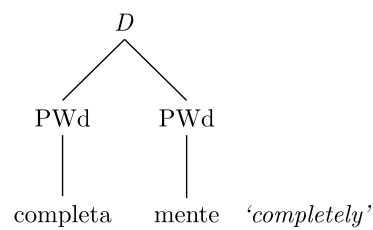

Figure 3

Prosodic status of the elements in each composite structure. Here, $D$ stands for 'domain'.

Before turning to examine what $D$ refers to in each of the constructions in Figure 3, a final note about the prosodization of stressed affixes is in order. It has been proposed that these affixes can be prosodized as feet instead of PWds (Vogel 2010). However, the representation of stressed suffixes as feet in BP would violate the Headedness principle, according to which the prosodic status of the structure head must be identical to or higher than the prosodic status of the non-heads in 
its domain (see, e.g., Zec 2005). More specifically, if the head element in a given domain is a PWd, the non-heads can be PWds, feet or syllables, but not PPhs. Conversely, if the non-head corresponds to a PWd, the head must correspond either to a PWd or to a higher domain, but not to a domain lower than the PWd. Considering that the prosodic head in composite constructions corresponds to the primarily stressed element, in word + stressed suffix structures, the head is the suffix (see (c) in Figure 3). If stressed suffixes corresponded to feet, Headedness would be violated. The representations for stressed affixes in Figure 3 (see (b) and (c)) thus respect Headedness, since the status of the head is identical to the status of the non-head.

In this section, I examined the phonological behaviour of word-word compounds and stressed affix + word structures in order to demonstrate that, although such structures are similar with regard to the application of several phonological processes, they differ in one fundamental respect, namely the stress patterns that they display. In addition, I provided evidence that each element in such composite structures corresponds to an independent PWd: they bear stress and undergo phenomena that target PWds. I argued, following the literature on both Brazilian and European Portuguese, that the behaviour of stressed affix + word structures with regard to ellipsis in coordination reinforces the PWd status of such affixes. In the next section, I discuss the prosodic representation of these composite constructions in view of their phonological differences, to account for the unspecified $D$ labels in Figure 3.

\section{THE PROSODIC REPRESENTATION OF BP COMPOSITE STRUCTURES}

Word-word compounds and stressed affix + word structures in BP have several phonological similarities and thus have been assigned the same prosodic representation (Silva 2010, Toneli 2014). However, as seen in the previous section, these structures exhibit an important difference with regard to stress patterns.

Table 3 summarizes the similarities and differences in phonological behaviour between word-word compounds and stressed affix + word structures. Stressed affix + word structures are divided into two categories, namely stressed prefix + word constructions and word + stressed suffix constructions. The cells in bold show the phenomenon that is important for differentiating among these constructions, as detailed in Section 3.

All types of composite structures in Table 3 exhibit vowel raising in final position in each of their elements, and both word-word compounds and stressed prefix + word constructions display vowel sandhi processes between their elements. Additionally, all composite structures in Table 3 preserve their lower mid vowels. Based on the premise that prosodic domains show consistency in the application of phonological phenomena, an analysis that considers only vowel raising, vowel sandhi and the behaviour of lower mid vowels would assign both word-word compounds and stressed affix + word structures to the same prosodic domain.

Examination of an additional phonological phenomenon, however, has revealed an important distinction in prosodic behaviour between word-word compounds 


\begin{tabular}{llll}
\hline Phenomenon & Word-word compounds & Stressed prefix + word & Word + stressed suffix \\
\hline Vowel raising & $\begin{array}{l}\text { in both members: } \\
\text { pront[u]-socorr[u] }\end{array}$ & $\begin{array}{l}\text { in both members: } \\
\text { vic[i]-president[i] }\end{array}$ & $\begin{array}{l}\text { in both members: } \\
\text { suav[i]-ment[i] }\end{array}$ \\
\hline Vowel sandhi & $\begin{array}{l}\text { applies: } \\
\text { empurr[i]mpurra }\end{array}$ & $\begin{array}{l}\text { applies: } \\
\text { vic[i]nspetor }\end{array}$ & NA \\
\hline $\begin{array}{l}\text { Lower mid vowel } \\
\text { preservation }\end{array}$ & $\begin{array}{l}\text { yes: } \\
\text { bota-fora }\end{array}$ & $\begin{array}{l}\text { yes: } \\
\text { pre-escola }\end{array}$ & $\begin{array}{l}\text { yes: } \\
\text { completa-mente }\end{array}$ \\
\hline Stress & $\begin{array}{l}\text { on both members; } \\
\text { retraction possible only } \\
\text { in the context of clash }\end{array}$ & $\begin{array}{l}\text { on both members; } \\
\text { retraction and advancement } \\
\text { possible to parallel patterns } \\
\text { in individual PWds }\end{array}$ & $\begin{array}{l}\text { on both members; } \\
\text { retraction and advancement } \\
\text { possible to parallel patterns } \\
\text { in individual PWds }\end{array}$ \\
\hline
\end{tabular}

Table 3

Behaviour of composite structures in BP.

and stressed affix + word structures: stress in stressed affix + word structures can be repaired to reflect the patterns in single PWds; word-word compounds, on the other hand, exhibit primary stress on each of their members and show stress retraction in the context of clash. If these two types of structures had exactly the same prosodic configuration, their stress patterns would be expected to be identical.

The parallels in phonological behaviour between these constructions are captured by the proposal that both are formed by independent PWds, as shown in Figure 3. In order to capture the phonological differences between these constructions, I propose that word-word compounds and stressed affix + word structures are prosodized in separate domains.

To avoid the reintroduction of an additional domain into the prosodic hierarchy, one possibility to account for the prosodization of these composite structures would be to assign stressed affix + word structures to a recursive PWd level and word-word compounds to the PPh. However, as shown in Section 3.2, wordword compounds and phrases differ with respect to the application of vowel sandhi processes when the second vowel is stressed: sandhi is allowed in PPhs in this environment, if the main stress of the structure is not on the second vowel involved in the process (see examples in (16)); in word-word compounds, on the other hand, sandhi is blocked even if the main stress of the construction where the compound is inserted is not on the second vowel (see examples in (17)). Therefore, word-word compounds cannot correspond to PPhs in BP.

Instead, I propose that while stressed affix + word structures are prosodized recursively in the PWd domain, word-word compounds are prosodized in an additional prosodic domain located between the PWd and the PPh, namely the composite group (CG) (compare (b) and (c) with (a) in Figure 4). Thus, the present analysis considers that the prosodic hierarchy both supports recursive domains (following, e.g., Inkelas 1990, Selkirk 1996) and contains an additional domain 
(a) word-word compound

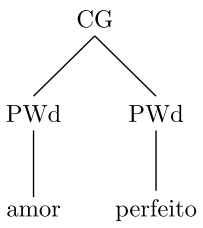

(b) stressed prefix + word

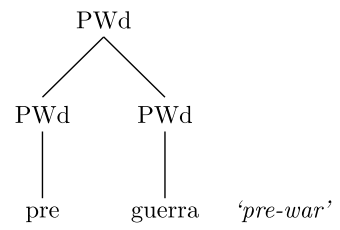

(c) word + stressed suffix

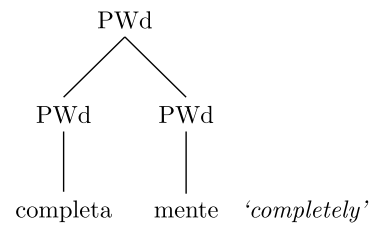

Figure 4

Prosodic representation of composite structures in BP.

for the representation of certain composite structures (following Vigário 2007, 2010; Vogel 2008, 2009).

The view that prosodic domains can be recursive and the view that the prosodic hierarchy contains a domain specific to the representation of composite structures have traditionally been assumed to be mutually exclusive. However, a prosodic hierarchy in which domain recursion is allowed is not incompatible with a prosodic hierarchy that contains such an additional domain. Domain recursion and the additional domain (the CG) serve different purposes, and thus the existence of the former does not preclude the existence of the latter. While the CG accommodates certain composite structures and thus is the domain of application for specific phonological processes, the possibility of domain recursion constrains prosodic adjunction.

In other words, the postulation of the additional category CG is justified based on the existence of structures that exhibit phonological processes that match neither those of PWds nor those of PPhs. This is precisely what is observed in word-word compounds in BP: as seen in the previous section, their phonological behaviour is not equivalent to that of independent PWds, stressed affix + word structures, or PPhs. The inclusion of prosodic recursion, on the other hand, is justified based on the observation that when certain structures (such as prefixes or suffixes) attach to a fully formed prosodic domain, the resulting construction undergoes processes that are characteristic of that domain. As seen in Section 3.2, when stressed affixes attach to fully formed PWds in BP, the resulting construction can be assigned stress according to the BP algorithm for PWd stress.

As previously mentioned, each element in stressed affix + word structures is stressed. However, the combination of the stressed affix and an independent word resulting in a higher PWd allows the PWd stress algorithm to reapply. In this case, prominence in the first element of the construction can be adjusted in accordance with the algorithm for secondary stress assignment. Primary stress is not affected since, unlike secondary stress, its position does not vary in BP. Structures that arise through adjunction therefore do not exhibit processes that are specific to their recursive status, but undergo processes that are associated with the domain in which they are prosodized. In that sense, prosodic adjunction refers to the attachment of a given element to a fully formed structure (in this case, an affix that attaches to a fully formed PWd). The position taken here is thus more constrained 
than analyses in which recursive levels can be domains for processes independent of those observed to hold for non-recursive domains (e.g. Peperkamp 1997b, Ito \& Mester 2013, Elfner 2015; see also Martinez-Paricio 2012).

One consequence of the present proposal is that prosodic adjunction should be allowed for all cases where a given structure can attach to a fully formed prosodic domain. This means that prosodic recursion would be allowed not only for the PWd domain, but for all domains to which a prosodic adjunct can attach. This in effect seems to be the case for BP stressed prefixes, which can attach not only to fully formed PWds, but also to fully formed word-word compounds. For example, the stressed prefixes vice and super can attach to the word-word compound primeiro-ministro 'prime minister'. The evidence for proposing that these stressed prefixes attach to the word-word compound as a whole (instead of to its first element) comes from the observation that stress on the prefixes cannot advance to the right, even though there is a lapse between the stress on the prefix and the stress on the first element of the compound (33). As seen earlier in (24), when a stressed prefix attaches to a fully formed word (thus forming a recursive $\mathrm{PWd}$ ), stress on the prefix can move to the right when there is a lapse between the stress on the prefix and the stress on the host word. Figure 5 shows the prosodic representation of word-word compounds to which a prefix attaches.

(33) Blocking of stress advancement in prefix + word-word compounds:

(a) více priméiro minístro $\rightarrow$ více/*vicé priméiro minístro vice prime minister

(b) súper priméiro minístro $\rightarrow$ súper/*supér priméiro minístro super prime minister

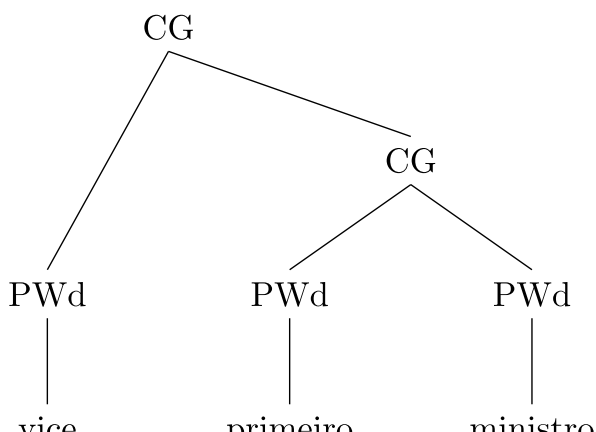

'vice prime minister'

Figure 5

Recursive CG: stressed prefix + word-word compound.

Composite groups can also be recursive when independent words adjoin to them. For example, in BP, word-word compounds can have adjuncts to their left (e.g. porta in porta-guarda-chuva lit. holder keep rain 'umbrella holder') or to their right (e.g. chave in dedo-duro-chave lit. finger hard key 'key snitch'). 
Adjunction of an independent PWd to a fully formed compound is signalled through particular pitch (in the case of adjunction to the left) and duration patterns (in the case of adjunction to the right) (Guzzo 2017), which is consistent with the proposal that such structures are formed through adjunction and are thus recursive. This type of compound formation can also be found in other Romance languages, for example Italian (see Bisetto (2010) for discussion about recursion in compounds such as porta-asciuga-mani lit. holder-dry-hand 'towel holder', which have an identical structure to porta-guarda-chuva in BP).

The proposal advanced in this paper is thus also a response to one particular criticism directed at the use of recursion in prosodic representation, namely the fact that recursive levels are often the domain of application for specific phonological processes (Vogel 2009, Vigário 2010), which contradicts the fundamental premise in prosodic theory that phonological processes are constrained to prosodic domains (not to recursive levels). In effect, if both prosodic domains (such as the PWd) and recursive levels (such as the recursive PWd) can be domains of application for distinct processes, it is not clear in what manner prosodic domains differ from recursive levels. It is often the case that structures whose prosodization is assigned to a recursive level differ substantially from structures whose prosodization is assigned to a non-recursive level in the same domain. In this case, it is not clear why such structures are assigned to a recursive level instead of to a novel domain in the prosodic hierarchy. As mentioned above, the present proposal considers that processes that are specific to a given domain can reapply in its recursive levels, although no novel processes should have the recursive levels as their context of application.

Another problem for recursive representations is the fact that recursive levels often show an overlap in process application with higher domains in the prosodic hierarchy. This is particularly a challenge for the representation of BP stressed affixes in recursive levels. At this point, then, a note on the configuration of the recursive $\mathrm{PWd}$ in $\mathrm{BP}$ is appropriate.

In $\mathrm{BP}$, unstressed monosyllabic prefixes that attach to fully formed words (e.g. re-fazer 're-do', co-produzir 'co-produce') have been proposed to prosodize recursively in the PWd domain (e.g. Schwindt 2001). As mentioned in Section 3.2, these unstressed prefixes do not exhibit vowel raising or undergo vowel sandhi processes (if the adjacent word starts with a vowel). In other words, unstressed prefixes seem to behave as PWd-internal pretonic syllables in the language. However, unlike pretonic syllables (see footnote [14]), when these unstressed prefixes contain upper mid vowels, they are not affected by the presence of a high vowel in the following syllable.

These observations indicate that there is a PWd boundary between the unstressed prefix and its host, and that this prefix is prosodized in a recursive PWd level, as shown in Figure 6. Therefore, under this proposal, both unstressed prefix + word structures and stressed prefix + word structures would be prosodized as recursive PWds. One question then arises: How can structures prosodized in the same node (i.e. as recursive PWds) display such differences in phonological behaviour? 


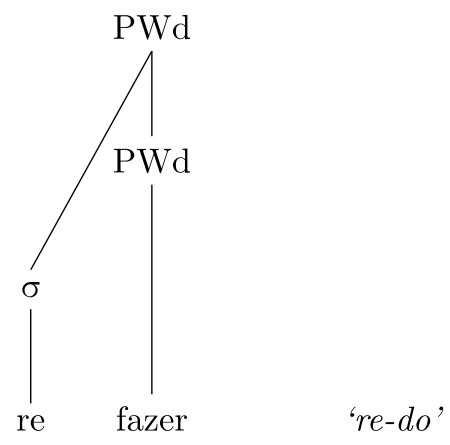

Figure 6

Prosodic representation of unstressed prefix + word constructions.

The differences in phonological behaviour between structures with stressed and unstressed prefixes are consistent with the prosodic category of the elements within the recursive structure. In stressed prefix + word structures, the prefix is equivalent to a PWd (see (b) in Figure 4), and thus displays PWd processes, such as vowel raising in final position and sandhi with the initial vowel of the host word. In unstressed prefix + word structures (Figure 6), the prefix corresponds to an independent syllable within the PWd domain, which thus cannot exhibit vowel raising or sandhi processes.

In the case of stressed prefix + word structures, it is not the prosodic status of the combination of elements, but rather the status of each of the elements, that conditions the application of vowel raising and vowel sandhi in the construction. A recursive representation, in this context, captures the fact that a prefix whose phonological behaviour is equivalent to that of a PWd attaches to another PWd. It also captures a fundamental difference between constructions with stressed affixes and word-word compounds: while stressed affix + word structures arise through adjunction to the same domain of the host word, word-word compounds are formed from the combination (or sum) of elements.

Therefore, the view that prosodic domains can be recursive is not incompatible with the view that considers the existence of an additional domain between the $\mathrm{PWd}$ and the $\mathrm{PPh}$ in the prosodic hierarchy. Whereas recursive domains emerge through prosodic adjunction and account for the prosodization of structures with stressed affixes in BP, the additional domain (CG) functions as the domain of prosodization of word-word compounds. The analysis presented here thus supports the reintroduction of an additional domain between the PWd and the $\mathrm{PPh}$ in the prosodic hierarchy. Figure 7 shows the revised version of the prosodic hierarchy, which replaces the clitic group with the CG.

In summary, the critical difference between word-word compounds and stressed affix + word structures lies not in their internal prosodic configuration, but in the domain to which such constructions are assigned. The fact that the PWd algorithm for secondary stress assignment can override the position of stress in the first element of stressed affix + word structures indicates that these structures 


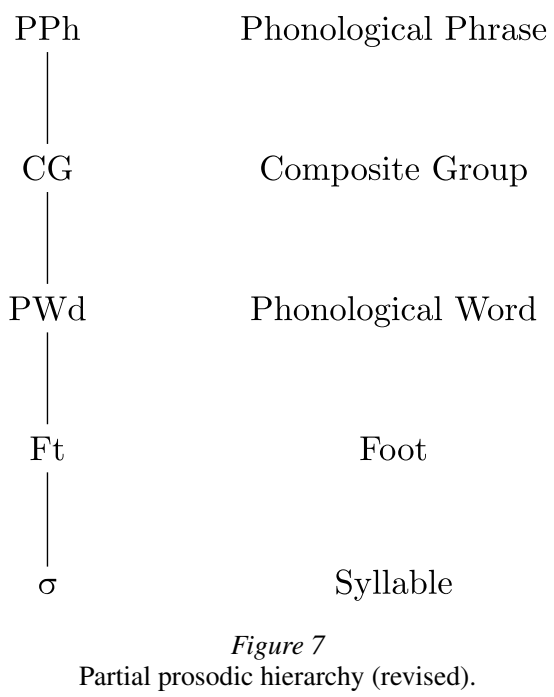

are prosodized in the PWd domain. Word-word compounds, on the other hand, differ from stressed affix + word structures with respect to the stress patterns that they exhibit, and from PPhs with respect to the application of vowel sandhi processes when the second targeted vowel is stressed. These differences support the prosodization of word-word compounds in a domain between the PWd and the PPh.

\section{FINAL REMARKS}

In this paper, I have shown that word-word compounds and stressed affix + word structures in BP are prosodized in distinct domains. While stressed affix + word structures are prosodized in the PWd, word-word compounds are prosodized in the CG, the constituent located between the PWd and the PPh proposed by Vogel (2008, 2009).

The main phonological difference between word-word compounds and constructions with a stressed affix was argued to be related to the stress patterns displayed by them: each element of word-word compounds behaves as an independent word with regard to stress assignment, whereas stressed affix + word structures can be assigned secondary stress according to the PWd algorithm.

Given their inherent prominence and the phonological processes that they undergo (namely vowel raising and vowel sandhi), each element in word-word compounds and stressed affix + word constructions was shown to correspond to a PWd. Thus, the present analysis assumes that the prosodic hierarchy admits recursive levels and contains an additional domain between the PWd and the $\mathrm{PPh}$. While prosodic domains are still assumed to serve as environments for phonological process application, recursion accounts for the adjunction of elements (such as BP stressed affixes) to fully formed structures. 
The proposal presented in this paper has some similarities to that of Vigário (2007, 2010), who demonstrates that the phonological behaviour of compounds formed by independent PWds in European Portuguese is consistent with their representation in the prosodic word group (a domain equivalent to the $\mathrm{CG}$ ), not in the $\mathrm{PPh}$. The present study diverges from Vigário's work by providing evidence that certain morphological structures with internal PWd configuration (namely stressed affix + word structures) correspond not to an independent domain but to a recursive domain.

The BP data explored in this paper thus indicate that the proposal according to which there is an additional domain between the PWd and the PPh in the prosodic hierarchy is not incompatible with the proposal according to which prosodic domains can be recursive, unlike what has been assumed in previous analyses (e.g. Selkirk 1996, Vogel 2009). While I have argued that recursion is constrained to contexts (in both the PWd and the CG) where the recursive structure exhibits the same phonological behaviour as the lowest instance of the domain, further research is necessary to determine whether the same limitations hold for other domains of the prosodic hierarchy. Additionally, further work is required to investigate which additional structures can be accommodated by the $\mathrm{CG}$ in a prosodic hierarchy that admits recursion.

\section{REFERENCES}

Abaurre, Maria Bernadete. 1996. Acento frasal e processos fonológicos segmentais [Phrasal stress and segmental phonological processes]. Letras de Hoje 31.2, 41-50.

Abaurre, Maria Bernadete, Charlotte Galves, Arnaldo Mandel \& Filomena Sandalo. 2006. Secondary stress in two varieties of Portuguese and the Sotaq optimality based computer program. Probus 18, 97-125.

Battisti, Elisa. 1993. Elevação das vogais médias pretônicas em sílaba inicial de vocábulo na fala gaúcha [Raising of pretonic mid vowels in word-initial syllable in southern Brazil]. MA thesis, Universidade Federal do Rio Grande do Sul.

Bauer, Laurie. 1998. When is a sequence of two nouns a compound in English? English Language and Linguistics 2, 65-86.

Bisetto, Antonietta. 2010. Recursiveness and Italian compounds. SKASE Journal of Theoretical Linguistics 7, 14-35.

Bisol, Leda. 1981. Harmonia vocálica: Uma regra variável [Vowel harmony: A variable rule]. Ph.D. dissertation, Universidade Federal do Rio de Janeiro.

Bisol, Leda. 1992. O acento e o pé métrico binário [Stress and the binary metric foot]. Cadernos de Estudos Linguísticos 22, 69-80.

Bisol, Leda. 2003. Sandhi in Brazilian Portuguese. Probus 15, 177-200.

Bisol, Leda. 2009. O alçamento da pretônica sem motivação aparente [Unmotivated raising of pretonic mid vowels]. In Leda Bisol \& Gisela Collischonn (eds.), Português do sul do Brasil: variação fonológica. Porto Alegre: EDIPUCRS.

Câmara, Joaquim Mattoso Jr. 1970. Estrutura da língua portuguesa [The structure of the Portuguese language]. Petrópolis: Vozes.

Collischonn, Gisela. 1994. Acento secundário em português [Secondary stress in Portuguese]. Letras de Hoje 29.4, 43-55.

Elfner, Emily. 2015. Recursion in prosodic phrasing: Evidence from Connemara Irish. Natural Language \& Linguistic Theory 33.4, 1169-1208.

Gayer, Juliana Escalier Ludwig. 2014. Uma análise da elisão e da degeminação com base em restrições. [A constraint-based analysis of elision and degemination]. Ph.D. dissertation, Universidade Federal do Rio Grande do Sul. 
Gravina, Aline Peixoto \& Flaviane Fernandes-Svartman. 2013. Interface sintaxe-fonologia: Desambiguação pela estrutura prosódica no português brasileiro [Syntax-phonology interface: Disambiguation through prosodic structure in Brazilian Portuguese]. Alfa 57.2, 639-668.

Guzzo, Natália Brambatti. 2015. A prosodização de clíticos e compostos em português brasileiro [The prosodic representation of clitics and compounds in Brazilian Portuguese]. Ph.D. dissertation, Universidade Federal do Rio Grande do Sul.

Guzzo, Natália Brambatti. 2017. Recursion in Brazilian Portuguese complex compounds. In Ruth Lopes, Juanito Ornelas de Avelar \& Sonia Cyrino (eds.), Romance Languages and Linguistic Theory 12. Selected papers from the 45th Linguistic Symposium on Romance Languages (LSRL). Amsterdam: John Benjamins.

Hayes, Bruce. 1989. The prosodic hierarchy in meter. In Paul Kiparsky \& G. Youmans (eds.), Rhythm and meter, 201-260. Orlando: Academic Press.

Hermans, Ben \& Leo Wetzels. 2012. Productive and unproductive stress patterns in Brazilian Portuguese. Revista Letras \& Letras 28, 77-114.

Inkelas, Sharon. 1990. Prosodic constituency in the lexicon (Outstanding Dissertations in Linguistics), New York: Garland Press.

Ito, Junko \& Armin Mester. 1986. The phonology of voicing in Japanese: Theoretical consequences for morphological accessibility. Linguistic Inquiry 17, 49-73.

Ito, Junko \& Armin Mester. 2007. Prosodic adjunction in Japanese compounds. In Yoichi Miyamoto \& Masao Ochi (eds.), MIT Working Papers in Linguistics 55: Formal Approaches to Japanese Linguistics 4, 97-111. Cambridge, Massachusetts.

Ito, Junko \& Armin Mester. 2009. The extended prosodic word. In Janet Grijzenhout \& Baris Kabak (eds.), Phonological domains: Universals and deviations, 135-194. Berlin: Mouton de Gruyter.

Ito, Junko \& Armin Mester. 2013. Prosodic subcategories in Japanese. Lingua 124, 20-40.

Kubozono, Haruo. 1995. Constraint interaction in Japanese phonology: Evidence from compound accent. In Rachel Walker, Ove Lorentz \& Haruo Kubozono (eds.), Phonology at Santa Cruz, vol. 4, 21-38. UC Santa Cruz: Linguistics Research Center.

Lee, Seung Hwa. 1997. Sobre os compostos do PB [On compounds in Brazilian Portuguese]. DELTA $13,17-33$.

Lee, Seung Hwa. 2002. Acento secundário do PB [Secondary stress in Brazilian Portuguese]. Letras de Hoje 37, 149-162.

Lee, Seung Hwa. 2013. Interface fonologia-morfologia: Diminutivos no PB [Phonology-morphology interface: Diminutive structures in Brazilian Portuguese]. Diadorim special volume, 113-125.

Leite, Yonne \& Dinah Callou. 2002. Como falam os brasileiros [How Brazilians speak]. Rio de Janeiro: Zahar.

Lieber, Rochelle \& Pavol Stekauer. 2009. Introduction: Status and definition of compounding. In Rochelle Lieber \& Pavol Stekauer (eds.), The Oxford handbook of compounding. Oxford: Oxford University Press.

Martinez-Paricio, Violeta. 2012. Superfeet as recursion. In Nathan Arnett \& Ryan Bennett (eds.), Proceedings of the 30th West Coast Conference on Formal Linguistics, 259-269. Somerville, MA: Cascadilla Proceedings.

Moreno, Cláudio. 1997. Morfologia nominal do português: Um estudo de fonologia lexical [Nominal morphology of Portuguese: A study in lexical phonology]. Ph.D. dissertation, Pontifícia Universidade Católica do Rio Grande do Sul.

Nespor, Marina \& Angela Ralli. 1996. Morphology-phonology interface: Phonological domains in Greek compounds. The Linguistic Review 13.3-4, 357-382.

Nespor, Marina \& Irene Vogel. 1986. Prosodic phonology. Dordrecht: Foris.

Oliveira, Marco Antônio de. 1992. Aspectos da difusão lexical [Aspects of lexical diffusion]. Revista de Estudos da Linguagem 1, 31-41.

Partee, Barbara. 1994. Lexical semantics and compositionality. In Lila Gleitman \& Mark Liberman (eds.), Invitation to cognitive science - Part I: Language. Cambridge: MIT Press.

Peperkamp, Sharon. 1997a. The prosodic structure of compounds. In Gabriela Matos, Matilde Miguel, Inês Duarte \& Isabel Hub Faria (eds.), Interfaces in linguistic theory, 259-279. Lisbon: APL/Colibri.

Peperkamp, Sharon. 1997b. Prosodic words. Ph.D. dissertation, Holland Academic Graphics, University of Amsterdam, The Hague.

Prince, Alan \& Paul Smolensky. 1993/2004. Optimality Theory: Constraint Interaction in Generative Grammar. Rutgers University and University of Colorado at Boulder, 1993. Revised version published by Blackwell, 2004. 


\section{NATÁLIA BRAMBATTI GUZZO}

Rio-Torto, Graça \& Sílvia Ribeiro. 2012. Portuguese compounds. Probus 24, 119-145.

Sandalo, Filomena \& Hubert Truckenbrodt. 2003. Some notes on phonological phrasing in Brazilian Portuguese. DELTA 19.1, 1-30.

Schwindt, Luiz Carlos. 2001. O prefixo no português brasileiro: Análise prosódica e lexical [Prefixes in Brazilian Portuguese: A lexical and prosodic analysis]. DELTA 17.2, 175-207.

Schwindt, Luiz Carlos. 2008. Revisitando o estatuto prosódico e morfológico de palavras prefixadas do PB em uma perspectiva de restrições [Revising the prosodic status and the morphological status of prefixed words in Brazilian Portuguese through a constraint-based approach]. Alfa: Revista de Lingüística 52.2, 391-404.

Schwindt, Luiz Carlos. 2013. Neutralização da vogal pretônica e formação de palavras em português brasileiro [Neutralization of pretonic vowels and word formation in Brazilian Portuguese]. Organon 28.54, 137-154.

Selkirk, Elisabeth. 1984. Phonology and syntax: The relation between sound and structure. Cambridge, MA: MIT Press.

Selkirk, Elisabeth. 1986. On derived domains in sentence phonology. Phonology 3, 371-405.

Selkirk, Elisabeth. 1996. The prosodic structure of function words. In James L. Morgan \& Katherine Demuth (eds.), Signal to syntax: Bootstrapping from speech to grammar in early acquisition, 187-214. Mahwah, NJ: Lawrence Erlbaum Associates.

Selkirk, Elisabeth. 2011. The syntax-phonology interface. In John Goldsmith, Jason Riggle \& Alan Yu (eds.), The handbook of phonological theory, 435-483. Oxford: Blackwell.

Silva, Taís Bopp da. 2010. Formação de palavras compostas em Português Brasileiro: Uma análise de interfaces [Compound word formation in Brazilian Portuguese: An interface analysis]. Ph.D. dissertation, Universidade Federal do Rio Grande do Sul.

Tenani, Luciani Ester. 2002. Domínios prosódicos no português [Prosodic domains in Portuguese]. Ph.D. dissertation, Universidade Estadual de Campinas.

Toneli, Priscila Marques. 2014. A palavra prosódica no português brasileiro [The prosodic word in Brazilian Portuguese]. Ph.D. dissertation, Universidade Estadual de Campinas.

Toneli, Priscila Marques, Marina Vigário \& Maria Bernadete Abaurre. 2014. Distinguishing emphatic and prosodic word initial stress: Evidence from Brazilian Portuguese. Proceedings of the 4th International Symposium on Tonal Aspects of Languages, 172-176.

Vigário, Marina. 2003. The prosodic word in European Portuguese, vol. 6. Berlin: Walter de Gruyter.

Vigário, Marina. 2007. O lugar do grupo clítico e da palavra prosódica composta na hierarquia prosódica: Uma nova proposta [The place of the clitic group and the composite phonological word in the prosodic hierarchy: A new proposal]. In Maria Lobo \& Maria Antónia Coutinho (eds.), Actas do XXII Encontro Nacional da Associação Portuguesa de Linguística - Textos seleccionados, 673-688.

Vigário, Marina. 2010. Prosodic structure between the prosodic word and the phonological phrase: Recursive nodes or an independent domain? Linguistic Review 27, 485-530.

Vigário, Marina \& Flaviane Fernandes-Svartman. 2010. A atribuição de acentos tonais em compostos no português brasileiro [Pitch accent assignment in Brazilian Portuguese compounds]. Textos selecionados do XXV Encontro Nacional da Associação Portuguesa de Linguística, 769-786.

Vigário, Marina \& Sónia Frota. 2002. Prosodic word deletion in coordinate structures. Journal of Portuguese Linguistics 1, 241-264.

Villalva, Alina. 1994. Estruturas morfológicas: Unidades e hierarquias nas palavras do português [Morphological structures: Units and hierarchies in words in Portuguese]. Ph.D. dissertation, Universidade de Lisboa.

Vogel, Irene. 2008. The morphology-phonology interface: Isolating to polysynthetic languages. Acta Linguistica Hungarica 55.1, 205-226.

Vogel, Irene. 2009. The status of the clitic group. In Janet Grijzenhout \& Baris Kabak (eds.), Phonological domains: Universals and deviations, 15-46. Berlin: Mouton de Gruyter.

Vogel, Irene. 2010. The phonology of compounds. In Sergio Scalise \& Irene Vogel (eds.), Crossdisciplinary issues in compounding, 145-163. Amsterdam: John Benjamins Publishing.

Wetzels, Leo. 1992. Mid vowel neutralization in Brazilian Portuguese. Cadernos de Estudos Linguísticos 23, 19-55.

Zec, Draga. 2005. Prosodic differences among function words. Phonology 22.1, 77-112.

Author's address: McGill University, Department of Linguistics, 1085 Dr Penfield Avenue, H3A 1A7, Montreal, QC, Canada nataliaguzzo@me.com 